\title{
Engineering Geology of the Government Hill Area, Anchorage, Alaska
}

\section{U.S. GEOLOGICAL SURVEY BULLETIN 1588}

A cooperative research project between the U.S. Geological Survey and the State of Alaska Division of Geological and Geophysical Surveys

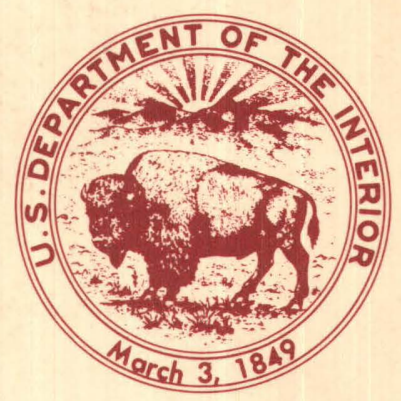





\section{Engineering Geology of the Government Hill Area, Anchorage, Alaska}

\section{By RANDALL G. UPDIKE and BRUCE A. CARPENTER}

A cooperative research project between the U.S. Geological Survey and the State of Alaska Division of Geological and Geophysical Surveys

A geotechnical parametric characterization of the late Quaternary sediments which underlie the transportation-industrial center for south-central Alaska, with particular reference to earthquake hazards 


\title{
DEPARTMENT OF THE INTERIOR \\ DONALD PAUL HODEL, Secretary
}

\author{
U.S. GEOLOGICAL SURVEY \\ Dallas L. Peck, Director
}

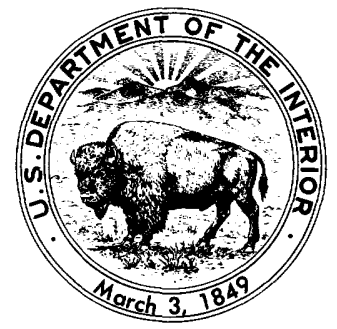

UNITED STATES GOVERNMENT PRINTING OFFICE, WASHINGTON: 1986

For sale by the

Books and Open-File Reports Section

U.S. Geological Survey

Federal Center

Box 25425

Denver, CO 80225

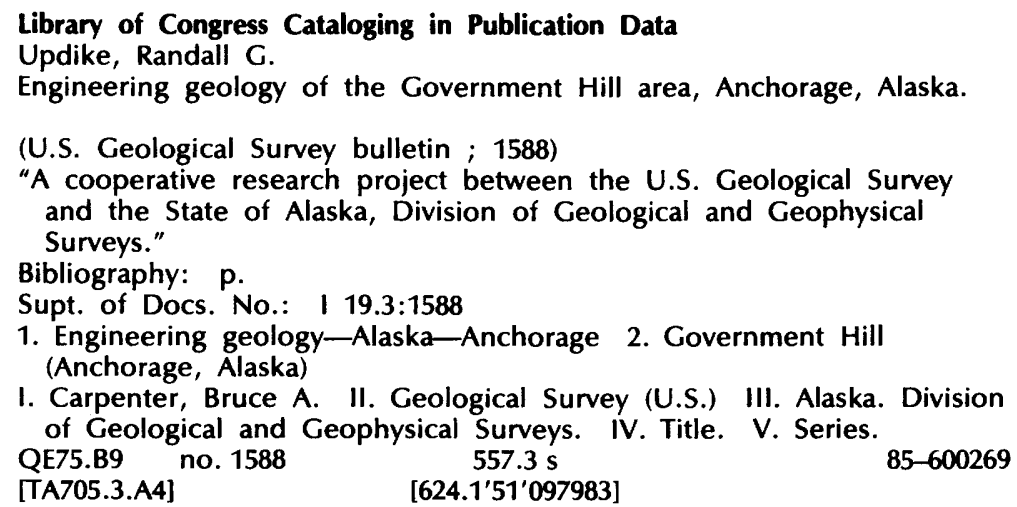




\section{CONTENTS}

Glossary of terms used $\mathbf{v}$

Abstract 1

Introduction 1

Scope of this investigation 2

Acknowledgments 2

General geologic setting $\mathbf{3}$

Techniques of investigation 6

Fieldwork 6

Subsurface data compilation and assessment 7

Description of engineering geologic units 8

Introduction 8

Bootlegger Cove Formation 8

Distinction of facies $\mathbf{8}$

F.I, clay with very minor amounts of silt and sand 8

F.II, silty clay and (or) clayey silt 9

F.III, silty clay and (or) clayey silt, sensitive 9

F.IV, silty clay and clayey silt with silt and sand layers 9

F.IVA, silty clay and clayey silt with silt and fine sand lenses 9

F.IVB, silty clay with traces of coarse sand $\mathbf{1 0}$

F.V, silty clay and (or) clayey silt with random stones 10

F.VI, dense silty fine sand with silt and clay layers 10

F.VII, fine to medium sand with traces of silt and gravel $\mathbf{1 0}$

Textural characteristics of the facies $\mathbf{1 0}$

Geotechnical characteristics of the facies 12

Post-Bootlegger Cove Formation glaciofluvial deposits 16

Tidal flat and tidal marsh deposits 17

Landslide deposits 19

Fluvial deposits associated with modern drainage 22

Man-related fill deposits $\mathbf{2 2}$

Surface and ground-water hydrology 23

Behavior of the engineering geologic units 24

Liquefaction 25

Sensitive silty clays 29

Other mechanisms 30

Summary $\mathbf{3 0}$

References cited 31 


\section{FIGURES}

1. Photographs showing Government Hill area and Anchorage Port facilities 2

2. Photograph of Government Hill area, looking east 4

3. Sketch map showing location of study area 5

4. Generalized map showing regional tectonic setting of Cook Inlet region 6

5. Example of subsurface geotechnical data retrieval system card 7

6-10. Graphs showing:

6. Plot of coarsest 1 percentile versus median diameter for samples of the Bootlegger Cove Formation 12

7. Correlation of shear strength and unconfined compressive strength for samples of cohesive facies of the Bootlegger Cove Formation 16

8. Correlation of mean shear strength and mean compressive strength, for cohesive facies of the Bootlegger Cove Formation 16

9. Correlation of mean undisturbed shear strength and mean sensitivity ratio for cohesive facies of the Bootlegger Cove Formation 17

10. Correlation of mean sensitivity ratio and mean liquidity index for cohesive facies of the Bootlegger Cove Formation 17

11. Photograph of exposure in a landslide block, showing glaciofluvial deposits of the Naptowne glaciation of Karlstrom (1964) overlying the Bootlegger Cove Formation 18

12. Composite drawing of idealized stratigraphic sequence of tidal flat deposits 19

13. Map showing distribution of landslides in Government Hill area 20

14. Photograph showing 1964 Government Hill School landslide 21

15. Map showing inferred direction of unconfined ground-water flow into uplands of Government Hill area 24

16-18. Graphs showing:

16. Determination of $\mathrm{C}_{N}$ as a function of effective overburden pressure 28

17. Liquefaction potential for tidal flat sands and glaciofluvial sands 29

18. Liquefaction potential for tidal flat silty sands and F.VI 29

TABLES

1. Comparison of mean textural variations of the seven facies of the Bootlegger Cove Formation, Government Hill area, Anchorage, Alaska 11

2-8. Summaries of engineering-soils properties of facies of the Bootlegger Cove Formation, Government Hill area

2. F.I 12

3. F.II 13

4. F.III 13

5. F.IV 14

6. F.V 14

7. F.VI 15

8. F.VII 15

9. Qualitative assessment of liquefaction potential for engineering-geologic units, Bootlegger Cove Formation, Government Hill area, Anchorage, Alaska 26

10. Tabulation of borehole data and computed values utilized to evaluate liquefaction potential 27 
active fault $A$ fault is active if, because of its present tectonic setting, it can undergo movement from time to time in the immediate geologic future, or has shown evidence of movement during the Holocene (last 10,000 years).

aseismic Herein the term refers to behavior of soils and (or) structures under non-earthquake conditions.

attenuation A decrease in seismic amplitude during transmission as a result of geometrical spreading and variations of the physical properties of the transmitting medium; absorption and scattering of the energy waves.

Atterberg limits Two tests, suggested by Atterberg, which determine the moisture content at the upper and lower limits of the moisture range within which a soil exhibits the properties of a plastic solid.

cyclic stress The subjection of a rock or soil element to a series of alternating shear stresses which may vary in magnitude and orientation in a random fashion. The resultant forces being exerted on the element are termed "cyclic loading."

diamicton A general term for a nonlithified clastic sedimentary deposit which is poorly sorted and composed of coarse clasts (sand to boulders) set in a clayey silt matrix. Typically, diamictons are not stratified but may have a clast fabric and crude large-scale bedding.

dry density $\left(\gamma_{d}\right)$ The weight of the dry solid particles in a unit volume of soil.

effective stress $\left(\bar{\sigma}_{v}\right)$ The total stress exerted on a plane of a soil element minus the pore-water pressure; this stress in turn controls certain aspects of soil behavior.

facies, engineering geologic A sedimentary unit (soils unit) possessing the characteristics of a geologic facies, but in addition, defined on the basis of engineering soils criteria that are dictated by the geologic history and ambient conditions of the unit.

facies, geologic Any observable set of attributes, such as overall appearance, composition, or conditions of formation, of one part of a stratigraphic unit as contrasted with other parts of the same unit. These attributes define a sedimentary mass that may have irregular lateral boundaries; its upper and lower limits may not necessarily correspond with boundaries of the stratigraphic unit that contains them or with the upper and lower limits of other facies. A geologic facies may occur singly or repeatedly in a vertical section.

free face That part of the ground surface that stands more steeply than the general slope of the terrain above or below that slope. The lack of lateral buttress forces at the face allows the potential for displacement behind the face.

frequency The number of cycles occurring in unit time.

internal friction The resisting shear strength considered to be due to the interlocking of the soil grains and the resistance to sliding between the grains.

least-squares linear regression A statistical method for finding the equation of a straight line which best fits a set of data points, thus providing a relationship between two variables. liquefaction A condition wherein a soil will undergo continued deformation at a constant low-residual stress or with no residual resistance, due to the buildup and maintenance of high pore-water pressures which reduce the effective grain-to-grain pressure to a very low value.

liquid limit $\left(W_{l}\right)$ The minimum moisture content of a soil-water mixture at which the mixture will act as a viscous liquid.

liquidity index $(\mathrm{Li})$ An index equal to the difference between the natural moisture content and the plastic limit divided by the plasticity index; the index indicates the value of the natural moisture content relative to the Atterberg limits. A value greater than 1.0 suggests that, upon remolding, the soil would be transformed into a viscous liquid.

magnitude A logarithmic scale which is used to define an earthquake in terms of the motion that would be measured by a standard seismograph located $100 \mathrm{~km}$ from the epicenter of the earthquake.

natural moisture content $\left(W_{n}\right)$ The ratio of the weight of the water to the dry weight of the soil solids in a given soil mass.

Phi size $(\phi)$ The diameter of a soil particle as expressed by $-\log _{2}$ of diameter in millimeters.

plastic limit $\left(\boldsymbol{W}_{\boldsymbol{p}}\right)$ The minimum moisture content at which a soil mixture acts as a plastic solid.

plasticity index (PI) The numerical difference between the plastic limit and liquid limit of a soil; it represents the range of moisture content within which the soil exhibits the properties of a plastic solid.

pore-water pressure $(\boldsymbol{U})$ The pressure or stress transmitted through the pore water filling the voids of a soil.

sensitivity The loss of strength suffered by most natural clays when remolded at constant water content. The sensitivity ratio $(\mathrm{Sr})$ equals the original shear strength divided by the remolded shear strength.

shear strength (S) A measure of the ability of a soil to resist sliding along internal surfaces within the mass.

soil Here used in an engineering sense, soil refers to all of the unconsolidated mineral material at or near the Earth's surface, plus the air, water, organic matter, and other substances that may be included therein.

standard deviation A statistical measure of dispersion, the square root of the average of the squares of the deviations about the mean of a set of data.

standard penetration test (SPT) A means of estimating relative density and (or) unconfined compressive strength, which consists of driving a standard split-spoon sampler by dropping a $63-\mathrm{kg}$ mass from a height of $760 \mathrm{~mm}$. Penetration resistance is reported in number of blows necessary to drive the spoon $305 \mathrm{~mm}$.

stratigraphy The order of succession of the different sedimentary rock units (or soils units) that occur in an area.

unconfined compressive strength ( $q u$ ) The strength of a cylindrical soil sample in simple compression (no confining pressures), which is often used to describe the consistency of undisturbed cohesive soils. 


\title{
Engineering Geology of the Government Hill Area, Anchorage, Alaska
}

\author{
By Randall G. Updike ${ }^{1}$ and Bruce A. Carpenter ${ }^{2}$
}

\begin{abstract}
The Government Hill area and immediate vicinity have been the site of much of the early and continuing economic development of the City of Anchorage, particularly as the principal marine port and railway terminal for the region. Because many of the geological engineering problems that confront construction throughout Anchorage are manifest in the Government Hill-Ship Creek-Anchorage Port area, a detailed geotechnical study has been conducted here.

Late Quaternary glaciomarine and glaciofluvial sedimentation is primarily responsible for the sequence of sediments that directly underlie the Government Hill area. Most extensive of these sediments is the late Pleistocene Bootlegger Cove Formation. This formation has long been recognized as an engineering-soils unit likely to cause ground-stability problems when subjected to strong seismic-loading conditions. The static and dynamic geotechnical properties of these sediments have been evaluated by utilizing stratigraphic and geotechnical data from about 250 boreholes. The result of the analyses of these data has been the three-dimensional characterization of the engineering geology to $50 \mathrm{~m}$ below mean sea level.

Seven engineering geologic facies of the Bootlegger Cove Formation are distinguishable on the basis of our applying a series of sedimentologic and engineering parametric criteria, including particle size distribution, bedding structures and their interrelationships, Atterberg limits, natural-moisture content, natural density, shear strength, compressive strength, sensitivity, and standard penetration resistance. Five of the facies are cohesive silts and clays with varying amounts of sand and gravel as secondary constituents. The other facies are noncohesive and consist predominantly of coarse silt and sand. The cohesive facies accumulated in a re-
\end{abstract}

\footnotetext{
${ }^{1}$ Alaska Division of Geological and Geophysical Surveys, Eagle River, AK 99577.

${ }^{2}$ Present address Geraghty and Miller, Inc., Syosset, NY 11791.
}

stricted marine to freshwater basin; their variations result from fluctuations in sediment source and transport energy. The noncohesive facies represent glacial-fan delta and emergent tidal-flat deposition. Mapping the subsurface extent and relationship of individual facies has provided a better understanding of both the geologic history and present-day geotechnical characteristics of the formation.

One of the cohesive facies, F.III, is a sensitive silty clay which, when subjected to seismic shear stresses, exhibits rapid strength diminution. It is this facies that was responsible for the catastrophic landslides during the 1964 earthquake.

The liquefaction susceptibility of the sandy facies (F.VI and F.VII) has been examined using currently accepted techniques, and, based upon the existing data set, they do not appear to be liquefiable. A similar assessment of the liquefaction susceptibility of the Holocene tidal-flat sediments indicates that these soils are locally susceptible to seismically induced liquefaction.

Numerous prehistoric landslide deposits appear on essentially every slope surrounding the Government Hill upland. An examination of the local surface and groundwater hydrologic regime indicates that these waters significantly enhance slope stability problems within the Bootlegger Cove Formation. The multiplicity of the mapped translatory, rotational, and flowage-type landslides strongly suggests that similar slope failures will occur in the future. The potential for sensitive clay collapse in the upland areas of Government Hill and for liquefaction of sands and silty sands on the tidal flats and in the lower flood plain of Ship Creek should be carefully evaluated prior to future development of these areas.

\section{INTRODUCTION}

From a rather recent birth in 1914, Anchorage has expanded to become the population center for the State of Alaska. The early social and economic growth of the city was focused in the vicinity of lower Ship Creek. Set- 
tlement soon spread from the flood-plain tidal flat area to the adjacent uplands north (Government Hill) and south (Anchorage townsite) of Ship Creek (figs. 1, 2). Development in the following 25 years was essentially limited to these areas. The years from the beginning of World War II into the mid-1950's saw even further emphasis on the development of Government Hill and the near sealevel areas to the west and south into what has now become the land and sea transportation hub for south-central Alaska. The area of Government Hill-Anchorage PortShip Creek remains central to the growth and well-being of the entire region.

The natural setting of Anchorage has been quite conducive to its growth as a population and economic center. Topography in the Anchorage area is of low relief, gently sloping from the Chugach Mountains on the east toward Cook Inlet on the west and south (fig. 3). Much of the central part of Anchorage lies on a broad, gently sloping alluvial plain truncated by bluffs along Cook Inlet and along major streams flowing from the mountains to the inlet, the most important of which is Ship Creek. In addition to favorable topography, the region also offers a moderation of the more typical Alaskan climates, being warmer and wetter than the interior of the State and yet cooler and drier than most southern Alaska coastal areas. The climatic modification is a result of the surrounding mountain ranges and Cook Inlet. The climate and topography have provided the region with abundant water resources, through both surface runoff and ground-water aquifers, further stimulating socioeconomic growth.

One aspect of the regional geology which has been far less favorable to inhabitants of Anchorage is the regional seismicity. Earthquakes are felt by residents on a rather regular basis, usually causing little or no damage and only moderate alarm. However, the Prince William Sound earthquake, magnitude 8.4-8.6, of March 27, 1964, inflicted considerable destruction and loss of life in Anchorage, and its memory still lingers among longtime residents. Substantial damage occurred in the Government Hill-Anchorage Port area due to failure of structures, landslides, subsidence, and ground fissuring. Miraculously, no lives were lost.

The years since the 1964 earthquake have seen a rebuilding in this part of Anchorage with an ever-increasing emphasis on industrialization: the port has been modernized for military and civilian purposes; military, railroad, and private agencies store fuel supplies here; the Alaska Raiïroad has expanded its facilities. Moreover, the population of Government Hill has increased to about 5,000 residents. The continued industrial and transportation growth and development coupled with a rather dense population have emphasized the need for detailed engineering geologic study of the Government Hill area, with particular attention placed on earthquake-related hazards.

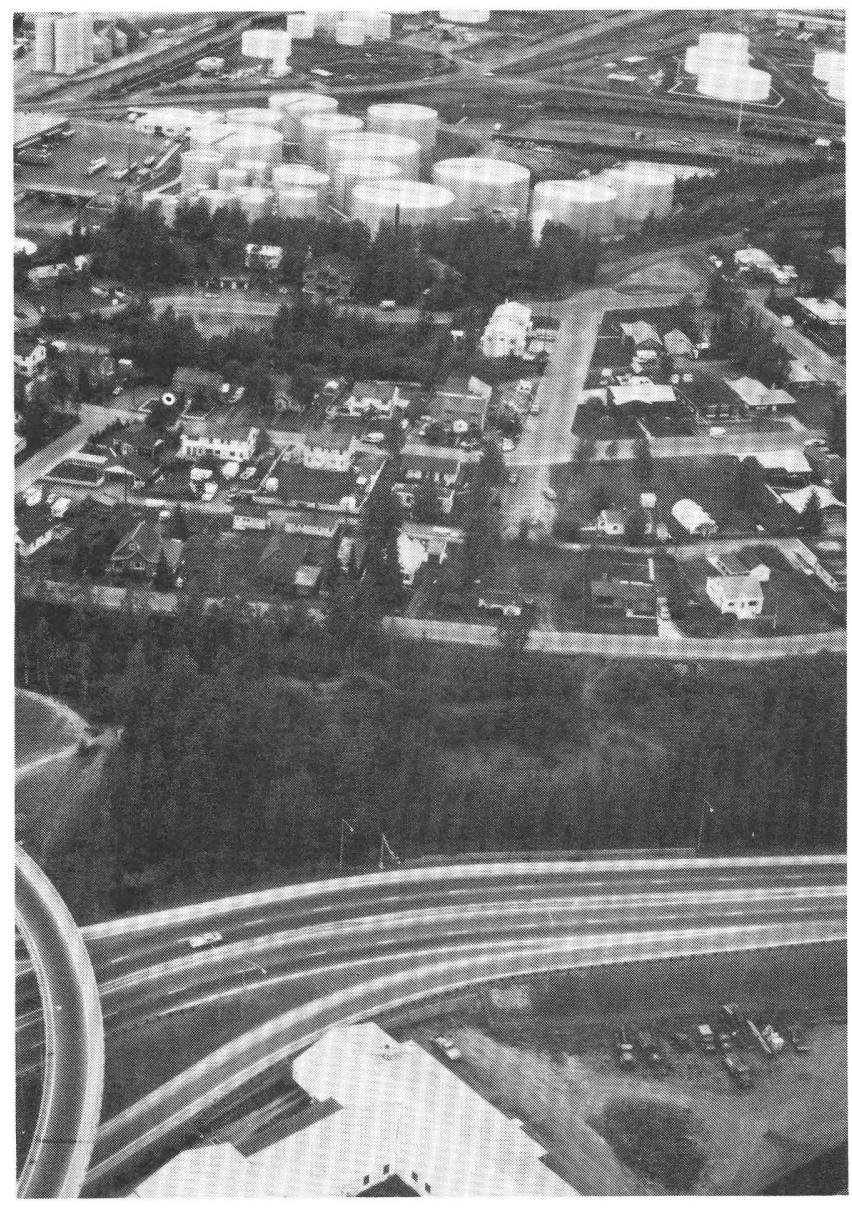

Figure 1. Oblique aerial photographs, Government Hill area. $A$, Juxtaposition of transportation, residential, and commercial uses in the area, which has had a history of ground failure.

\section{Scope of this Investigation}

The study of Government Hill and vicinity has two primary intents: (1) to accurately map the surface and subsurface geology at a scale that can be applied to sitespecific problems and (2) to evaluate this geology in terms of the area's geotechnical characteristics, particularly in light of the regional seismicity. The primary geologic hazard in the area is mass movement, which will be examined in relation to the mapping and parametric characterization of failure-susceptible units. The mapping phase has previously been completed under a separate report (Updike, 1986), and the text of the present report will occasionally refer to that report. The reader is encouraged to have the map in hand while reading the present report, which deals primarily with the second phase of the study.

\section{Acknowledgments}

This project was supported by a cooperative agreement between the U.S. Geological Survey (USGS) and 


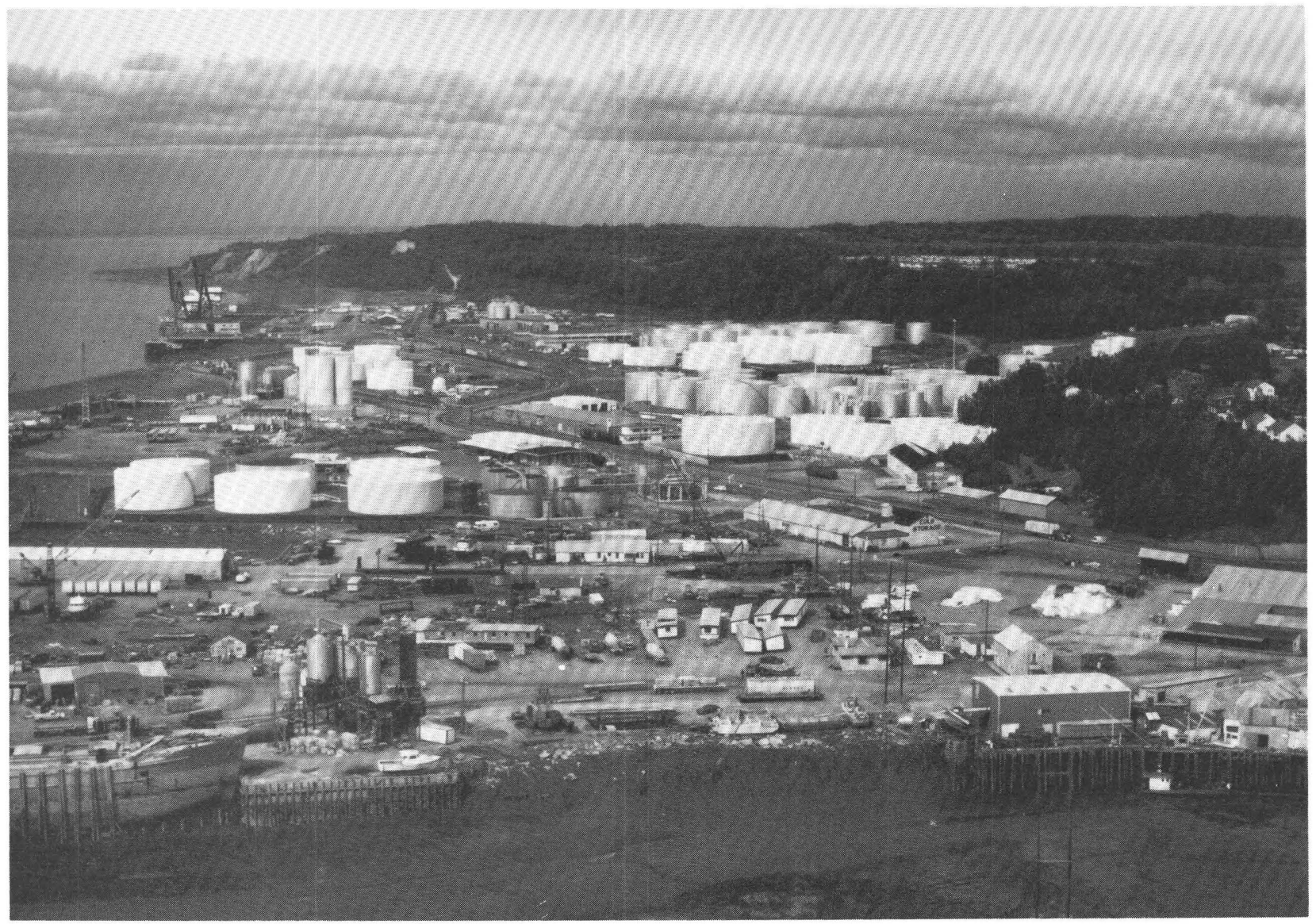

Figure 1-Continued. Oblique aerial photographs, Government Hill area. $B$, View, looking north, of petroleum storage tank farms and Anchorage Port facilities. Both views by R. G. Updike, 1980.

the Alaska Division of Geological and Geophysical Surveys, under the auspices of the USGS Earthquake Hazards Reduction Program. We wish to express special gratitude to D. J. Varnes of the USGS, Denver, for his assistance in providing the base maps and historic aerial photography from which the mapping was accomplished, as well as his advice and encouragement throughout the project. $\mathrm{H}$. E. Olsen (USGS, Denver) deserves special note, for it was through long conversations with him that the scope of this project evolved. We are also grateful for the advice and criticism of H. R. Schmoll (USGS, Denver), whose experience with upper Cook Inlet Quaternary stratigraphy proved very helpful.

Numerous governmental agencies and private organizations provided geotechnical data that form the heart of this study. The following individuals have been particularly helpful, providing not only their data but also their personal experiences and interpretations: Harry Lee and David Cole, DOWL Engineers; Cliff Fugelstadt, Alaska Railroad; Larry Pennington, Municipality of Anchorage; and Patrick Galbraith, U.S. Army Corps of Engineers.

Technical review of this report was provided by $T$. L. Youd (USGS, Menlo Park), and by D. J. Varnes, H.
R. Schmoll, and H. E. Olsen (all USGS, Denver). Their thorough efforts are most appreciated.

\section{GENERAL GEOLOGIC SETTING}

The active tectonic framework of the Anchorage region is evidenced both by the frequent occurrence of felt earthquakes and by the surface expression of active fault traces in nearby Quaternary deposits (fig. 4). Government Hill is located on the eastern shore of Knik Arm, itself a northeastern extension of Cook Inlet. During Quaternary time, this inlet has been influenced by fluctuations in sea level, advance and retreat of adjacent mountain glaciers, and tectonic subsidence and uplift. The geologic record produced by the interplay of these systems is indeed complex and certainly not fully understood by geologists, but some generalizations can be made.

The Greater Anchorage area, of which Government Hill is a part, lies on the eastern margin of the Cook Inlet forearc basin. This tectonic basin is bounded to the west by the Bruin Bay-Castle Mountain fault system and 
to the east by the Border Ranges fault system (formerly called Knik fault) along the front of the Chugach Mountains, east of Anchorage. Seismicity appears to be occurring along both fault systems as well as along the underlying Benioff Zone (Aleutian megathrust), which resulted from the subduction of the Pacific tectonic plate beneath the North American tectonic plate. Although, during a given time period, most seismic events occur along this zone of underthrusting (Fogelman and others, 1978), the likelihood of near-surface events on or adjacent to the surface fault systems is significant. Seismic activity related to the Castle Mountain system generally comprises low-magnitude shallow events $(M=3.0-4.5)$ even though the potential for larger magnitudes (greater than $M=6.0$ ) is quite real (John Lahr, oral commun., 1978). The unpublished work of investigators has shown evidence for low-magnitude seismicity along the mountain front, but uncertainty seems to prevail regarding the source of this seismicity.

The bedrock beneath the Anchorage lowland consists of Tertiary clastic sedimentary rocks which form a wedge lapping up to the east against the dominantly Mesozoic metamorphic rocks of the Chugach Mountains. No bedrock is exposed in the Anchorage lowland area, as it is generally $100-300 \mathrm{~m}$ below the surface and has been only rarely encountered even in deep boreholes.

A thick, nonlithified sedimentary sequence was deposited predominantly in Pleistocene time and modified by erosional processes during Holocene time. It is this surficial sequence that engineering and design problems focus on. The best summaries of the area's Quaternary history remain those of Karlstrom (1964), Miller and Dobrovolny (1959), and Schmoll and Dobrovolny (1972). Karlstrom proposed that at least five major glaciations occurred in upper Cook Inlet: the Mount Susitna, Caribou Hills, Eklutna, Knik, and Naptowne glaciations. The dates he established for some of these advances are now seriously questioned (for example, Schmoll and others, 1972; Reger and Updike, 1983), but the geomorphic and stratigraphic evidence still supports their use in the literature. The three earlier glaciations were presumably far more extensive than the later ones. Based upon stratigraphic

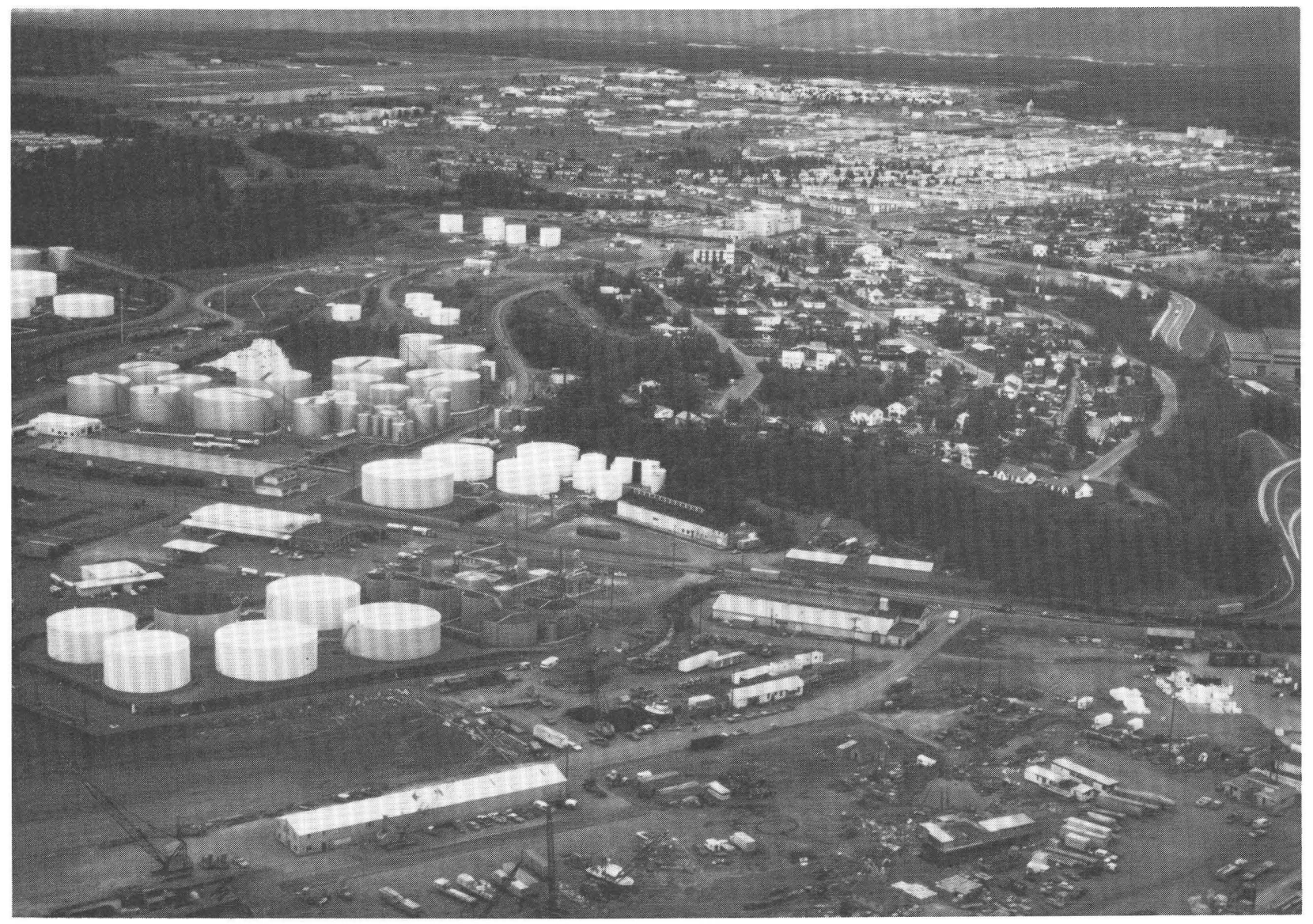

Figure 2. Oblique aerial photograph of Government Hill area, looking east. Elmendorf Air Force Base visible at upper left corner. Although individual landslides are not discernible in photograph, many of the petroleum storage tanks of middle distance are constructed on old landslides. The 1964 Government Hill Elementary School landslide lies in middle distance at right edge of photograph. (Compare fig. 14.) Photograph by R. G. Updike, 1979. 
and geomorphic criteria, Karlstrom (1964) envisioned that the ice of these earlier glaciations coalesced to fill the Cook Inlet trough. The two later glaciations were not extensive enough to fill the entire basin but did restrict or totally dam off lower Cook Inlet to form the so-called "Glacial Lake Cook." This lake could well have contained brackish and (or) fresh water during the many years of its existence (or multiple existences). Controversy continues regarding the time frame and extent of glaciers and lakes during middle and late Pleistocene time and, more specifically, the correlations that can be made between glaciofluvial, glaciodeltaic, glaciomarine, and true glacial tills within the basin. However, we do sense a general harmony among researchers that the Bootlegger Cove Formation, ${ }^{3}$ a stratified sequence of clastic sediments ranging from clay to boulders, was laid down during late Pleistocene time. Radiometric dates obtained by Schmoll and others (1972) indicate a late Wisconsin age for the upper part of the formation (about 14,000 years B.P.), which they interpret as predating the glacier advance to the Elmendorf Moraine. Paleontologic evidence supporting the contention that the formation was primarily deposited in

${ }^{3}$ This stratigraphic unit was originally named the Bootlegger Cove Clay by Miller and Dobrovolny (1959) for typical sections exposed at Bootlegger Cove, in Anchorage. Because the unit varies greatly in composition, and clay commonly is a secondary constituent, it has been redefined (Updike and others, 1982; Schmoll and others, 1984) as the Bootlegger Cove Formation, which is more consistent with the North American Stratigraphic Code usage applied when two or more rock types are common in a unit. marine waters (Schmidt, 1963) through a glacially restricted brackish environment cannot be disregarded. The stratigraphy of Government Hill indicates the following late Pleistocene events: (1) the deposition of stratified sands and gravels, now well below existing sea level, presumably from a glaciofluvial source to the north; (2) accumulation of the Bootlegger Cove Formation, presumably in a glaciomarine and (or) glaciolacustrine environment; and (3) deposition of late Wisconsin glaciofluvial sediments. The data from boreholes that penetrate the preBootlegger Cove deposits (about $10 \mathrm{~m}$ below the contact) show no evidence for till, though such till is believed to exist at greater depths. The Elmendorf Moraine (late Wisconsinan in age) occurs directly north of the project area, and the glaciofluvial deposits associated with it are both terraced and pitted (see description of mapped units following).

Since the late Pleistocene deposits accumulated, erosion of the sequence has occurred along the axis of Knik Arm and by major streams draining from the Chugach Mountains into the arm. This erosion has been accomplished through the hydraulic removal of tide-level material, coupled with mass wasting of bluffs, and both fluvial downcutting and lateral planation. These mechanisms have been strongly influenced by (1) eustatic changes in sea level, (2) vertical crustal movements (see Brown and others, 1977; Plafker, 1969), and (3) long-term fluctuations in stream regimen and hydraulic geometry (for example, the present underfit conditions of lower Ship Creek). Associated with this erosion has been the deposition of Holocene tidal-flat and fluvial deposits in the downcut areas, and the accumulation of landslide deposits along the retreating upland scarp faces.

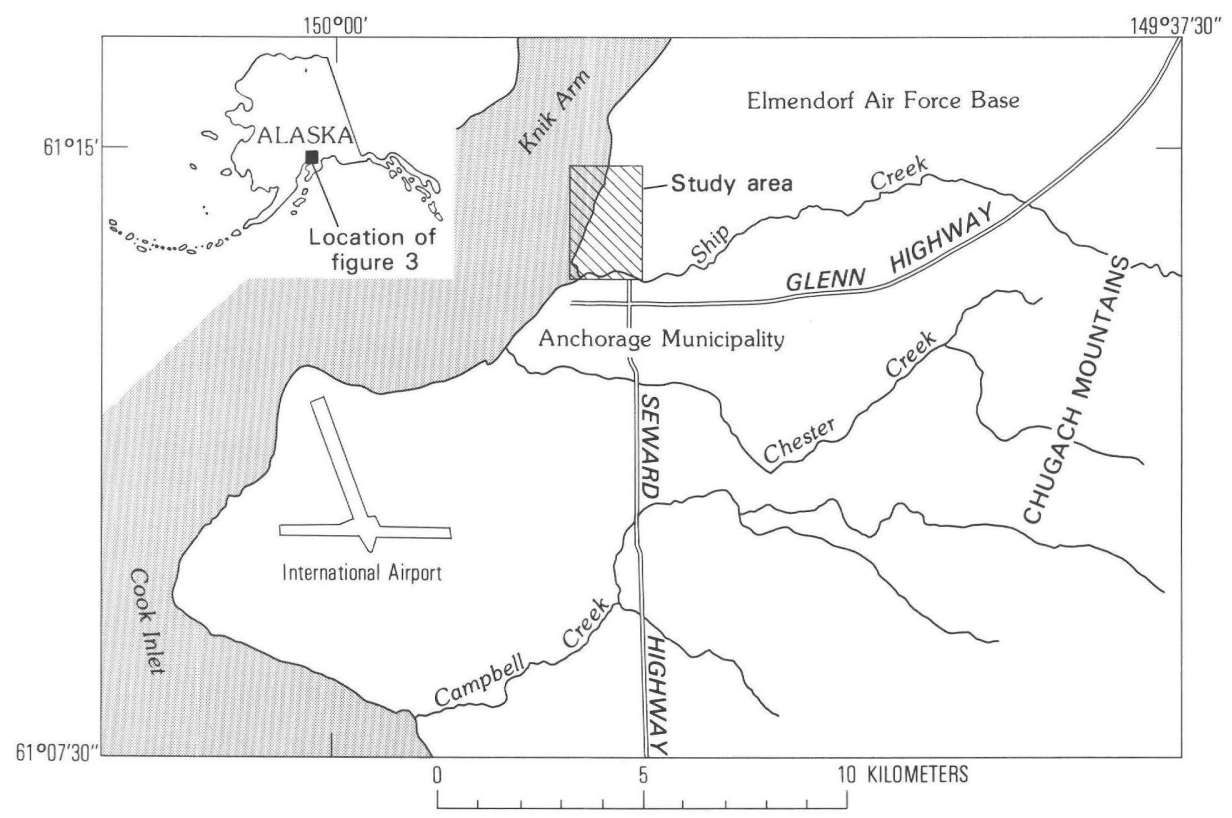

Figure 3. Location of the study area. 


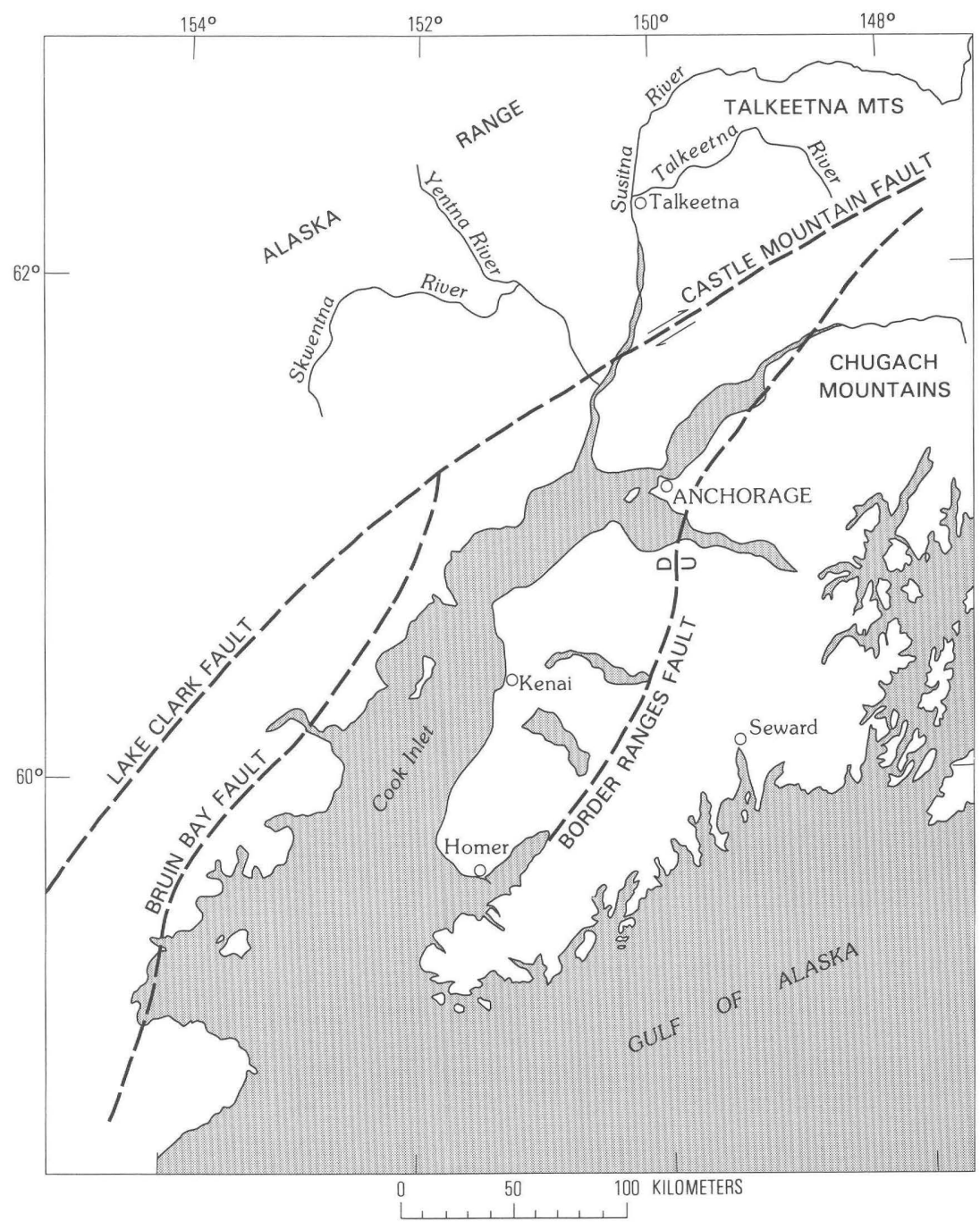

Figure 4. Generalized, regional tectonic setting of Cook Inlet region. Faults are approximately located; barbs show direction of movement; $U$, upthrown side; D, downthrown side.

\section{TECHNIQUES OF INVESTIGATION}

\section{Fieldwork}

The field-mapping program was conducted during the summer of 1979. Initially, a helicopter and groundbased reconnaissance of land bordering upper Cook Inlet was conducted to evaluate the variability of the Bootlegger Cove Formation. Particular note was made of compositional and stratigraphic variations, different modes of failure due to slides and flows, and the relation of this formation to other stratigraphic units. This work strongly suggested that the behavior of the Bootlegger Cove Formation is, in part, a function of local composition of the formation and also due to local hydrologic conditions.

Fieldwork within the mapped area involved detailed mapping of surficial geologic units using a topographic base map at a scale of 1:1,200, contour interval 2 feet. Concurrently, several sets of aerial photography were employed at various scales including USGS-M3738AUG50, 1:40,000; Mohawk ARD-U.S. Army M-64 76-4APR64, 1:1,826; Alaska RP-66-1002-100CT66, 1:4,265; DOT-AUG66, 1:2,823; Air Photo Tech ANC2MAY67, 1:24,000; U2-CIR-78-119-25AUG78. The mapping was accomplished using field exposures, handdug trenches, hand-augered drill holes, and geomorphology (both field observations and aerial photographs). Observations made at construction and excavation sites from July 1978 until July 1980 were also incorporated into the mapping. When field mapping was complete, the results were transcribed from the 1:1,200-scale maps and aerial photographs onto a 1:2,400-scale base map used for final publication (Updike, 1986). 


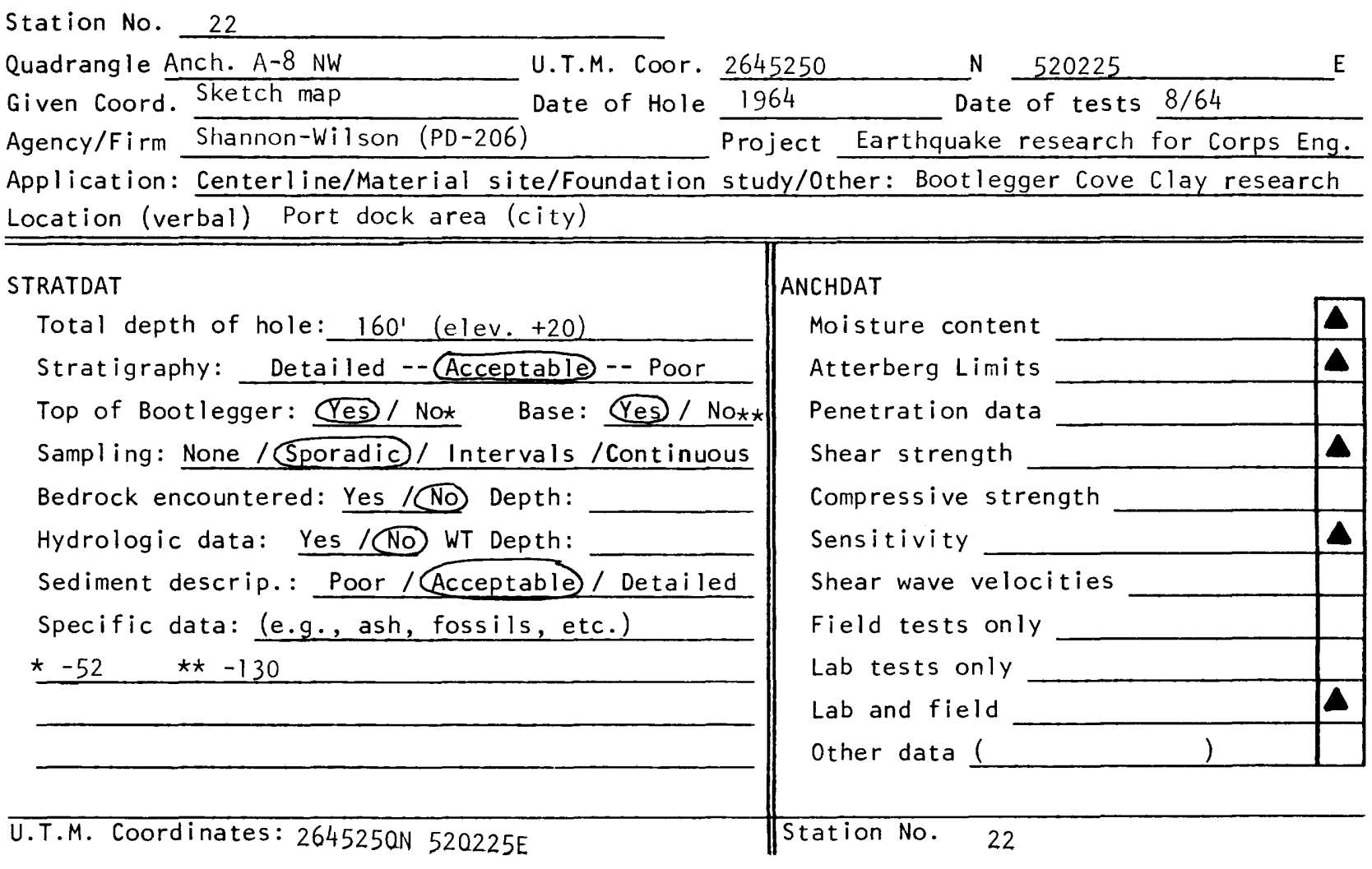

Figure 5. Example of subsurface geotechnical data retrieval system card utilized to catalog information used in present study. Triangle indicates that the listed geotechnical data (ANCHDAT) were reported for the specific borehole site. Verbal comments under STRATDAT are qualitative assessments of relative quality or quantity of data compared to other sites. Footnoted numbers under "specific data" are elevations in feet of top and base of the Bootlegger Cove Formation as reported in borehole log.

\section{Subsurface Data Compilation and Assessment}

Beginning in fall 1978, borehole data from geotechnical and hydrologic wells were collected by the authors from numerous Federal, State, municipal, and private sources. As of publication time (1985), $246 \mathrm{logs}$ and associated test data have been accumulated and compiled into catalog form using a standardized format (fig. 5). This format allows for recording of data available for each drill hole similar to a library retrieval card system, for both geologic (STRATDAT) and engineering (ANCHDAT) information.

Based on the field mapping and subsurface data bank, compatible stratigraphic map units were identified including the Bootlegger Cove Formation, post-Bootlegger Cove glaciofluvial sand and gravel units (Pleistocene), fluvial sediments associated with modern drainages (Holocene), tidal flat and tidal marsh sediments associated with modern Knik Arm (Holocene), landslide deposits (Holocene), and man-related fill deposits.

Specific attention was directed to the sedimentary successions of the Bootlegger Cove Formation. Seven facies were differentiated based on visual geologic and geotechnical characteristics, lateral extent and correlation, and transition probabilities. The facies states were then characterized by quantitative sedimentologic textural criteria, and this delineation of facies facilitated interpretation of stratigraphic successions and paleoenvironmental changes.

We have hypothesized that the nature of the facies variations, both vertical and lateral, could dictate the intraformational characteristics under both static and dynamic conditions. With this premise in mind, the engineering parameters for each facies were compiled using existing test data. Standard soils-engineering criteria were used including natural moisture content $\left(W_{n}\right)$, plastic limit $\left(W_{p}\right)$, liquid limit $\left(W_{l}\right)$ plasticity index (PI), liquidity index $(L i)$, shear strength (S), unconfined compressive strength $(q u)$, sensitivity (Sr), standard penetration (SPT), and dry density $\left(\gamma_{d}\right)$. Statistical tests were applied to the bulk data to reduce them to meaningful values.

The result of the above exercise has been the derivation of engineering geologic facies of the Bootlegger Cove Formation which are distinguished both by their particular geologic signature and by their geotechnical characteristics. These facies can be traced throughout the mapped 
area, providing a basis for interpreting paleoenvironmental changes and the resultant stratigraphic successions, and also for understanding and predicting the regional distribution of subsurface geotechnical conditions.

\section{DESCRIPTION OF ENGINEERING GEOLOGIC UNITS}

\section{Introduction}

Upon even casual examination of upper Cook Inlet and the glacially fed streams draining therein, one is impressed by the buff-gray, silt-laden waters which seem wholly uniform and ubiquitous throughout the region. The subsequent deposition, erosion, countless episodes of redistribution, and, ultimately, the burial of these fine sediments constitute the rule rather than the exception for Cook Inlet. The tidal flat muds of Turnagain and Knik Arms are the typical result of such cycles. In the bluffs bounding the inlet, a variety of Pleistocene clastic sedimentary units are exposed, but the most predictable constituents are stratified clays and silts which are essentially identical to analogs being laid down in the modern tidal inlet. We are led to conclude that the types of sedimentation have not altered dramatically in terms of texture.

\section{Bootlegger Cove Formation}

The older sediments of dominantly silt-clay texture which are exposed discontinuously about the perimeter of upper Cook Inlet have been referred to as the "Bootlegger Cove Clay" (Miller and Dobrovolny, 1959). Although earlier studies suggest that all such exposures mark the same stratigraphic unit, in recent years authors more commonly use phrases such as "Bootlegger Cove equivalent" and "Bootlegger Cove-type material," suggesting the unsettled question of regional correlation and contemporaneity. In visualizing, as Karlstrom (1964) did, a grand glacially dammed "Lake Cook," the regionality of a singular Bootlegger Cove unit becomes more plausible. Paleontologic studies (Schmidt, 1963; Smith, 1964) have indicated entirely marine microfauna, and geochemical studies by Kerr and Drew (1965) support that interpretation. In our opinion, insufficient evidence exists to make broad regional correlations of Bootlegger Cove correlatives, though such efforts have been successful for the Anchorage vicinity (for example, Barnwell and others, 1972).

The formation was recognized by Miller and Dobrovolny (1959) as having the potential to produce serious landslides, and, 5 years after their publication, this recognition was borne out by the massive failures resultant from the 1964 earthquake. Several publications soon followed, each focusing on the landslide hazards of the formation (for example, Shannon and Wilson, Inc., 1964; Hansen, 1965; Kerr and Drew, 1965, 1968; Long and George, 1966a, b; Seed and Wilson, 1967). In addition, the important role that the formation plays as a confining layer in the ground-water hydrologic system of the region was identified (for example, Cederstrom and others, 1964; Trainer and Waller, 1965; Barnwell and others, 1972) and continues to influence the viability of municipal water supplies.

\section{Distinction of Facies}

Our studies have identified seven facies, which usefully characterize the intraformational variation of the composition and geotechnical parameters. The examination of these facies in a spatial-stratigraphic framework provides a sharper image of how the Bootlegger Cove Formation relates to late Pleistocene events in upper Cook Inlet. Assuredly, facies are intricately intercalated so that the scale of units being defined as mappable facies is a concern. Generally, units less than $1 \mathrm{~m}$ thick will be considered as lenses or layers within a facies. As a function of depositional environment and postdepositional modifications-for example, normal consolidation and groundwater leaching, the engineering soils characteristics for a given facies can be summarized and contrasted with those of other facies of the formation. The facies (F) differentiated in the Bootlegger Cove Formation are:

F.I Clay with very minor amounts of silt and sand

F.II Silty clay and (or) clayey silt

F.III Silty clay and (or) clayey silt, sensitive

F.IVA Silty clay and clayey silt with silt and fine sand lenses

F.IVB Silty clay with traces of coarse sand

F.V Silty clay and (or) clayey silt with random stones

F.VI Dense silty fine sand with silt and clay layers

F.VII Fine to medium sand with traces of silt and gravel

In the following description of the facies, grain sizes are discussed in terms of phi units. The millimeter equivalents are as follows:

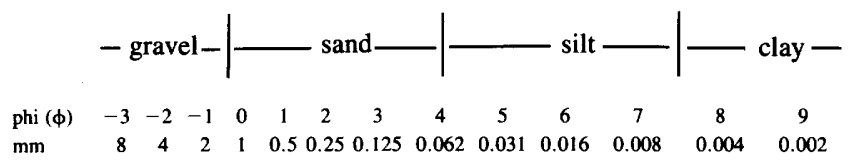

\section{F.I, Clay with Very Minor Amounts of Silt and Sand}

Although the Bootlegger Cove Formation is often referred to as a clay unit, most of the stratigraphic sequence is recognized to consist instead of abundant silt. Facies F.I is a notable exception in containing very small amounts of sediment coarser than $8 \phi$. The silt and fine- 
sand fractions usually occur as scattered grains and less commonly as thin discontinuous lenses a few millimeters thick, in a massive blue-gray to olive-blue-gray clay (Munsell Color Chart, $2.5 Y$ 4/0). Sedimentary structures (for example, bedding, partings, color changes) are exceedingly rare. Thickness of F.I varies from less than 1 $\mathrm{m}$ to more than $13 \mathrm{~m}$, but in this latter case some coarser lenses can be expected. Although the facies can locally be several meters thick, lateral continuity is lacking so that its occurrence in boreholes and in exposures is limited. Two general stratigraphic positions are suggested by elevations and succession; one is about present-day sea level (that is, about midpoint in the stratigraphic sequence) where it is bounded above and below by either F.III or F.IV; the other is in the upper part of the sequence where it is associated with F.II or F.IV below and F. VII or post-Bootlegger Cove sediments above.

\section{F.II, Silty Clay and (or) Clayey Silt}

This facies is one of the less extensive within the formation. Most of its occurrences are in the upper half of the Bootlegger Cove section, where it is generally thicker than $3 \mathrm{~m}$ but rarely thicker than $10 \mathrm{~m}$. Where it occurs lower in the section, bedding of the facies is more massive, that is, on the scale of several centimeters between horizons; higher in the section the tendency is toward thinner beds a few centimeters in thickness, each being distinguished by slightly different textures than those layers above and below. Contacts between horizons are rather abrupt, sometimes slightly inclined, but generally planar. Colors are blue gray to olive gray ( $2.5 Y 4 / 0$ to $5 Y 3 / 1$ ). Although the textural bedding is quite visible, textural analyses are significantly uniform and clasts coarser than $4 \phi$ are exceedingly rare.

\section{F.III, Silty Clay and (or) Clayey Silt, Sensitive}

The distinction of this facies from F.II and F.IV is based primarily on physical characteristics other than the traditional visual sedimentologic criteria. Generally, it is visually identical to the thicker bed examples of F.II but is distinguished by being much softer and more easily molded; on remolding, it exhibits a greatly diminished strength compared to its F.II counterpart. It nearly always occurs in the upper half of the section between about mean sea level (MSL) and $+15 \mathrm{~m}$ elevation. In almost all instances, it is bounded above and below by either F.II or F.IVA. In most places, either F.VI or F.VII is in very close stratigraphic proximity, a factor which may play a key role in interpreting the geologic history and behavior of this facies. F.III is often thinner than the other facies, usually ranging from less than $1 \mathrm{~m}$ to about 12 $\mathrm{m}$, but commonly less than $6 \mathrm{~m}$. For the purposes of stratigraphic description and correlation, the internal varia- bility of the facies in terms of texture and sensitivity is generalized, but it should be noted that discrete sand lenses as well as layers of stiffer silts and clays are present within F.III. In cores, several instances are recorded of fractures, near-vertical sand seams, silty partings at oblique angles, and what seem to be sheared bedding planes. These structures may have been produced in sampling, but we strongly believe that some may be products of the in-place strain history of the facies.

\section{F.IV, Silty Clay and Clayey Silt with Silt and Sand Layers}

We have chosen to subdivide this facies into F.IVA and F.IVB, based on textural distinctions visible in core samples and natural exposures. However, this distinction has not been mapped or distinguished under physical properties because the two variations of the F.IV have strong engineering similarities. This facies is the most abundant in the formation, and the discrimination of the subtle variations of F.IVA and F.IVB may become more critical in future studies.

\section{F.IVA, Silty Clay and Clayey Silt with Silt and Fine Sand Lenses}

This facies is the most common in the formation. It occurs throughout the project area in virtually every logged borehole, and likewise at nearly any vertical location in the section. Whereas most of the other facies have low probability of repeating in a given section, F.IVA can virtually be expected to reappear at different elevations within a given profile. Thicknesses of individual occurrences of F.IVA generally exceed $3 \mathrm{~m}$ and in some places approach $30 \mathrm{~m}$. Thin F.IVA horizons have been recorded above and (or) below F.III, and the authors believe these may sometimes represent prehistoric postdepositional strain events associated with the shearing, soil structure collapse, and subsequent consolidation of F.III, the sensitive facies. Bedding is prominent in F.IVA with thin seams and pockets of silt and sand interbedded with the finer clayey silt layers. Silt and fine sand grains are scattered throughout most of the facies, and thin clay seams occur here and there amidst the coarser layers. F.IVA bedding is more prominent in the upper part of the section where layers are a few centimeters thick. In some instances, the textural variation and bedding thickness are regular and appear cyclic, suggesting varves, but the connotations of varved sediments (that is, annual, lacustrine) are not suggested by the authors. Particular note should be taken of the fact that throughout most of the recorded profiles, F.IVA seems often to alternate with other facies states; and whereas the other states may only appear once or, at most, twice, in a given profile, F.IVA reappears to account for the major part of the profile. This would, it seems, suggest that this facies state may 
represent the overall regional norm for a depositional environment during the span of time represented by the Bootlegger Cove Formation, and that the other facies may represent subtle divergences from that norm.

\section{F.IVB, Silty Clay with Traces of Coarse Sand}

Another facies of considerable abundance is F.IVB. Here, the bedding is more massive than that of F.IVA and the clay-size fraction is dominant. The state is further distinguished by the often random scattering of coarse sand grains throughout the unit. Less commonly, the coarse sand occurs as very thinly laminated seams oriented nearly horizontally through the silty clay. In contrast to the facies heretofore described, F.IVB is usually found in the lower half of the Bootlegger Cove Formation, and in fact, generally either this facies or F.V (and rarely F.II) is the lowermost facies of the formation. This is interesting in that both are crudely bedded silty clays with randomly scattered coarser clasts. F.IVB can occur at or near the top of the Bootlegger Cove section, but such instances are rare. Although thicknesses may exceed 30 $\mathrm{m}$, seldom are they greater than $15 \mathrm{~m}$ or less than $3 \mathrm{~m}$.

\section{F.V, Silty Clay and (or) Clayey Silt with Random Stones}

Perhaps the single most distinctive facies of the formation is F.V. It has been noted to occur in the lower part of the Bootlegger Cove Formation throughout the region (Schmoll and others, 1972, p. 1107); at Government Hill, it primarily exists at elevations near or below MSL, so that no exposures of the facies are recorded. This facies does appear much higher in the section farther north at Cairn Point (Miller and Dobrovolny, 1959, p. 39), but no continuity can be drawn between these exposures and the project area due to poor intervening exposures and lack of subsurface data to the north. The facies is characterized by having (1) very weakly developed stratification, (2) poor sorting ranging from clay to boulders, with peak size abundance in the silt-clay range, (3) occasional disturbed laminations, and (4) irregular contacts with units above and below. F.V may well be classified as a diamicton.

\section{F.VI, Dense Silty Fine Sand with Silt and Clay Layers}

Although thin, discontinuous lenses of silty sand occur in F.I, F.III, F.IVA, and F.IVB, the presence of independently mappable sand layers is limited. However, at an elevation of between +12 and $+18 \mathrm{~m}$ above MSL, an unusually uniform and predictable F.VI layer can be traced in the subsurface of the eastern half of the mapped area. This layer appears to be a clastic wedge which has a maximum thickness of about $20 \mathrm{~m}$ in the northeast, splits into layers separated by other facies in the east-cen- tral area, and ultimately thins to about $3 \mathrm{~m}$ in the southeast. The unit is confined above and below by F.III and F.IV. F.VI is normally described as dense, indicating a well-packed structure with significant amounts of silt. Locally, however, borehole logs record this facies as "running," or "quicksand," suggesting loose packing and saturated conditions. Although thin lenses a few millimeters thick of silt and clay may be present, the facies is dominantly coarse silt to fine sand $(2-5 \phi)$. Other representatives of this facies occur at lower positions in the stratigraphic sequence but lack the remarkable lateral continuity exhibited by the aforementioned layer. In this sense, the F.VI unit appears to be a continuous stratigraphic horizon throughout the study area and to have been deposited at the same time in the same depositional environment over a broad area.

\section{F.VII, Fine to Medium Sand with Traces of Silt and Gravel}

In the uppermost part of the Bootlegger Cove stratigraphic sequence, a facies notably coarser than those previously described commonly appears. The facies consists predominantly of olive-gray, fine to medium sand $(1-4 \phi)$ with lenses of coarser sand and scattered pebbles. Generally, it is bounded above by post-Bootlegger Cove sediments (glaciofluvial sandy gravels). Although the sand normally is massive, faint bedding can sometimes be noted by subtle variations in the textural and color homogeneity of the sand. Silt is a typical minor constituent throughout, but only rarely assumes prominence as distinct silt lenses. The gravel is randomly dispersed and rarely approaches cobble size, being primarily rounded to subrounded pebbles less than $-3 \phi$ diameter. Contacts with other facies are generally abrupt but, for the most part, conformable. An alternation between thin layers of F.II, F.IV, and F.VII will in many places occur before the F.VII facies assumes predominance in the uppermost part of the section. If this facies proves to have regional extent in the same stratigraphic position beyond Government Hill, it may well merit member status within the formation.

\section{Textural Characteristics of the Facies}

The original field descriptions used by a variety of geologists and engineers logging the geotechnical boreholes were reduced by the authors; of an original 32 different descriptive units, 7 facies are presently being defined. The premise of using these facies is that each represents a slightly different sedimentologic environment during the history of deposition of the Bootlegger Cove Formation. The products of these varied depositional regimes should then be distinct from each other, and one basic criterion for this distinction should be texture. To test this reasoning, the textural analyses of 66 samples were as- 
Table 1. Comparison of the mean textural variations of the seven facies of the Bootlegger Cove Formation, Government Hill area, Anchorage, Alaska

[ $\phi$ equals negative log to the base 2 of diameter in millimeters]

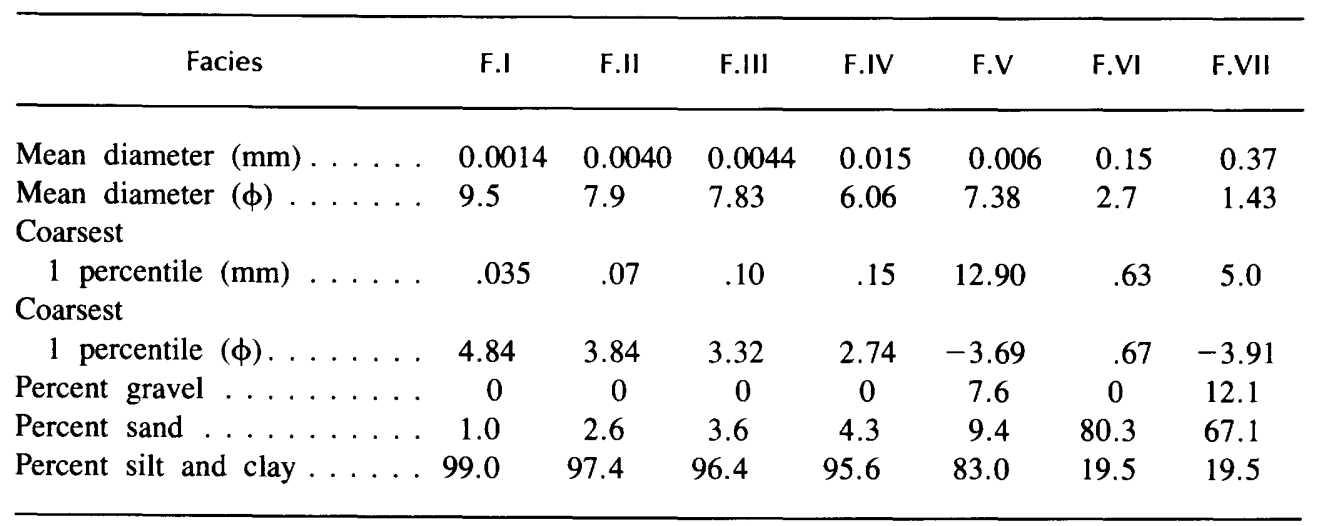

sembled and for each analysis four characteristics computed: (1) size frequency distribution, (2) mean grain size of sample, (3) size of coarsest 1 percentile of sample, and (4) size class distribution in percent of total by weight (table 1). Comparison of the sample description (upon which facies states were first defined) and the textural name based on the mechanical and statistical analyses demonstrated that the two (visual and quantitative) coincided in all but three cases. This significantly increased the credibility of the logging of the geotechnical holes and of the field geologic descriptions.

To further distinguish the textural variation of the facies, the C-M diagram of Passega (1957) is used, in which the mean grain size of the sample (M) is plotted against the grain size of the coarsest 1 percentile (C). This graphic representation has proven effective in defining transport regimes and depositional environments in mobile fluid environments such as flood plains (Passega, 1957), beach and marine systems (Passega, 1964), and fluidized flow of volcanic tephra (Sheridan and Updike, 1975). Each analysis was plotted by a reference number to avoid bias. Each data point was then identified to facies as defined by us. With only one exception, the data points were plotted into distinct facies domains (fig. 6). Mechanical analyses of post-Bootlegger Cove glaciofluvial deposits were also plotted describing an additional independent domain.

This figure shows two things: first, that the facies, as defined verbally, appear to exhibit real textural differences; second, that the depositional fluid regimes can be quantified. Domain pbg represents a group of sediment samples from post-Bootlegger Cove deposits that have both median and maximum grain sizes in the gravel class, typical of the well-sorted glaciofluvial deposits that one would observe in outwash fans and plains. In contrast, F.VII domain contains maximum clast sizes in the gravel range, but is dominantly sand, such as would occur along high-energy beach and tidal flats where sediment too coarse for continuous suspension transportation was being moved by tractive forces. Two of the data points in this domain are, in fact, modern tidal flat sand samples. The domain of the diamicton phase (F.V) is consistent with field descriptions, that is, scattered gravel set in a siltyclay matrix. As Passega (1957) pointed out, such divergency from the $C=M$ line often indicates two independent depositional functions in the same aqueous system. Under such conditions, traditional sedimentologic criteria such as the coefficient of sorting cannot be rigorously applied to express the character of deposition. The authors believe this domain indicates a quiet glaciomarine environment where the dominant mode of deposition is from a clayey-silt suspended load, with ice-rafted drop-stones sporadically introduced. F.VI domain closely parallels the $\mathrm{C}=\mathrm{M}$ line and consists of well-sorted fine sand. This sediment represents a boundary condition between tractive and suspension transport, as occurs in the intertidal to very shallow offshore regime. This boundary environment was probably strongly influenced by tidal conditions and renewed introduction of silty sand from subaerial sources. F.VI commonly contains thin lenses of silt and clay but very rarely clasts larger than medium sand, further supporting the suspension-traction threshold concept. The remaining domains of F.I, F.II, and F.IV are distinct from each other but also form a divergent pattern, suggesting the depositional variability that occurs in a large, quiet, perhaps tidally influenced, glaciomarine-glaciolacustrine environment. The extreme case of F.I would seem to require exceedingly quiet conditions, such as one might find in tidal flat depressions, isolated sloughs, and back-eddy basins that are periodically recharged with water and suspended sediment. F.III does not describe a distinct zone on the graph but instead is superimposed on F.II and F.IV. The reasons for this exception are elaborated later in this report. 


\section{Geotechnical Characteristics of the Facies}

The data bank of geotechnical boreholes in the project area was carefully screened by us, to acquire a file of engineering soils test data. The data were cataloged according to the defined geologic facies. Some data were rejected because of lack of stratigraphic control, questionable sampling techniques, or poorly defined laboratory procedures. Once the data had been processed, values for each parameter of each facies were ranked in ascending numerical order and the standard statistical values were computed: (1) the arithmetic mean, $\bar{X}$, (2) the median, Md, (3) the maximum value of the array, $X_{\max }$, (4) the minimum value of the array, $X_{\min }$, and (5) the standard deviation $\sigma_{x}$. Each of the standard geotechnical soils parameters for each facies was thus characterized, and the results of our calculations are presented in tables 2-8. The geotechnical parameters used for facies discrimination are defined in the glossary. For comparative purposes, the mean values of each physical property for each facies, as provided in tables $2-8$, are used in the graphic discriminations discussed later in this section.

The Atterberg limits, plasticity index, and liquidity index proved to be helpful, though inconclusive, tools in differentiating the cohesive soils facies (F.I to F.V). The mean natural moisture contents and plastic limits do not vary appreciably within the formation; however, the true clay material which predominates in F.I and the sensitive silt/clay material of F.III have the highest mean $W_{n}$. The plasticity indices of predominant constituents of F.I, F.II, F.IV, and F.V differ very little, whereas the mean plastic-

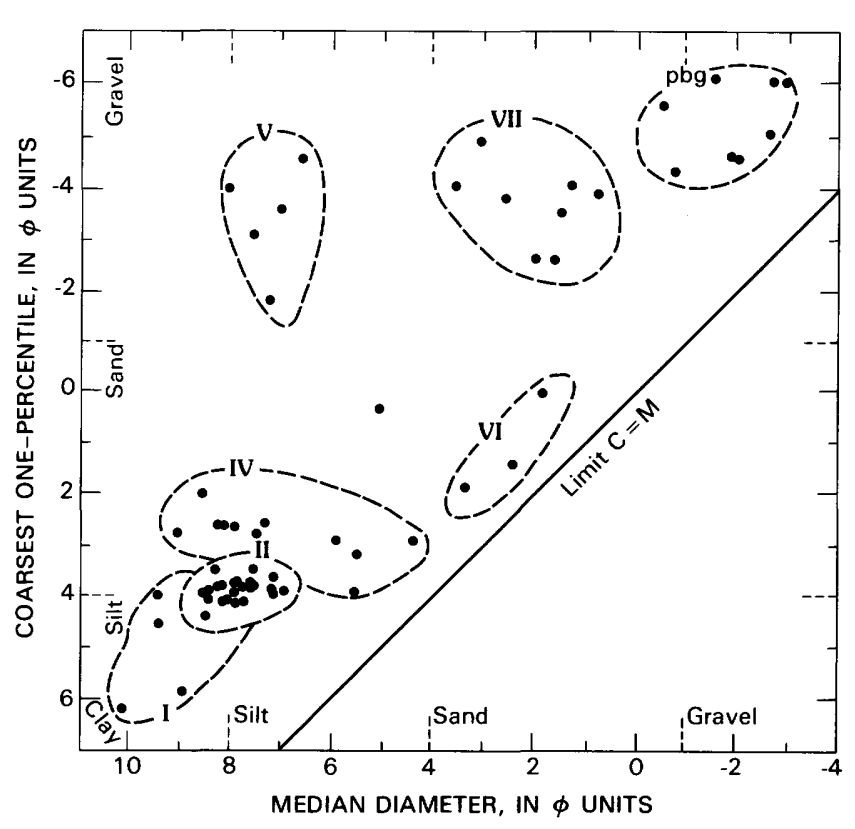

Figure 6. The C-M diagram of Passega (1964) used to plot coarsest 1 percentile $(C)$ versus median diameter $(M)$ for samples of the Bootlegger Cove Formation; diameters in phi $(\phi)$ notation. Facies domains discussed in text; pbg, post-Bootlegger Cove glaciofluvial deposits.

ity index for F.III is less than half of the value typical for the other facies. It appears that F.III differs from the other facies in that the liquid limit has shifted to such a low mean value that the moisture content of F.III is above the liquid limit. The liquidity index, $L i$, measures

Table 2. Summary of engineering-soils properties of F.I, Bootlegger Cove Formation, Government Hill area

[nd, not determined]

\begin{tabular}{|c|c|c|c|c|c|c|}
\hline & $\begin{array}{c}\text { Sample } \\
\text { array } \\
\text { size } \\
n\end{array}$ & $\begin{array}{c}\text { Mean } \\
\text { value } \\
\bar{x}\end{array}$ & $\begin{array}{c}\text { Maxi- } \\
\text { mum } \\
\text { value } \\
\text { of } \\
\text { array } \\
X_{\max }\end{array}$ & $\begin{array}{c}\text { Mini- } \\
\text { mum } \\
\text { value } \\
\text { of } \\
\text { array } \\
X_{\min }\end{array}$ & $\begin{array}{c}\text { Median } \\
\text { value } \\
\text { Md }\end{array}$ & $\begin{array}{c}\text { Standard } \\
\text { deviation } \\
\sigma_{x}\end{array}$ \\
\hline Thickness (meters) . . . . . . . . . . & 5 & 7.9 & 14.3 & 2.6 & 6.6 & $\left({ }^{1}\right)$ \\
\hline Moisture content (percent) . . . . . . . . & 13 & 29.8 & 37 & 23 & 30 & 3.9 \\
\hline Plastic limit (percent) $\ldots \ldots \ldots \ldots \ldots$ & 5 & 23.0 & 23 & 23 & 23 & 0 \\
\hline Liquid limit (percent) $\ldots \ldots \ldots \ldots$ & 9 & 39.0 & 45 & 35 & 40 & 3.3 \\
\hline Plasticity index . . . . . . . . & 7 & 16 & 20 & 13 & 16 & 2.3 \\
\hline Standard penetration $\ldots \ldots \ldots \ldots \ldots$ & 23 & 10.8 & 17 & 5 & nd & nd \\
\hline Shear strength $\left(\mathrm{kN} / \mathrm{m}^{2}\right) \ldots \ldots \ldots \ldots$ & 8 & 46.9 & 65.1 & 28.7 & 47.9 & 12.4 \\
\hline Compressive strength $\left(\mathrm{kN} / \mathrm{m}^{2}\right) \ldots \ldots \ldots$ & 5 & 161.8 & 241.3 & 134.1 & 143.6 & 40.2 \\
\hline Sensitivity ratio $\ldots \ldots \ldots \ldots \ldots$ & 3 & 8.7 & 10 & 8 & 8 & .94 \\
\hline
\end{tabular}

${ }^{i}$ Not applicable. 
Table 3. Summary of engineering-soils properties of F.II, Bootlegger Cove Formation, Government Hill area

[nd, not determined]

\begin{tabular}{|c|c|c|c|c|c|c|}
\hline & $\begin{array}{c}\text { Sample } \\
\text { array } \\
\text { size } \\
n\end{array}$ & $\begin{array}{l}\text { Mean } \\
\text { value } \\
\bar{x}\end{array}$ & $\begin{array}{c}\text { Maxi- } \\
\text { mum } \\
\text { value } \\
\text { of } \\
\text { array } \\
X_{\max }\end{array}$ & $\begin{array}{c}\text { Mini- } \\
\text { mum } \\
\text { value } \\
\text { of } \\
\text { array } \\
X_{\min }\end{array}$ & $\begin{array}{c}\text { Median } \\
\text { value } \\
\text { Md }\end{array}$ & $\begin{array}{c}\text { Standard } \\
\text { deviation } \\
\sigma_{x}\end{array}$ \\
\hline Thickness (meters) . . . . . . . . . & 12 & 7.8 & $>16.7$ & 3.3 & 6.6 & $(1)$ \\
\hline Moisture content (percent). . . . . . . & 77 & 28.4 & 40.0 & 16 & 27 & 4.4 \\
\hline Plastic limit (percent) . . . . . . . . & 44 & 22.1 & 25 & 17 & 23 & 2.3 \\
\hline Liquid limit (percent) $\ldots \ldots \ldots \ldots$ & 44 & 37.2 & 45 & 30 & 37 & 4.2 \\
\hline Plasticity index $\ldots \ldots \ldots \ldots \ldots$ & 44 & 15.1 & 24 & 5 & 15 & 3.9 \\
\hline Standard penetration. . . . . . . . . & 72 & 10.2 & 35 & 3 & nd & nd \\
\hline Shear strength $\left(\mathrm{kN} / \mathrm{m}^{2}\right) \ldots \ldots \ldots \ldots \ldots$ & 52 & 75.7 & 140.0 & 44.0 & 71.8 & 22.0 \\
\hline Compressive strength $\left(\mathrm{kN} / \mathrm{m}^{2}\right) \ldots \ldots \ldots$ & 65 & 142.7 & 308.3 & 50.8 & 120.7 & 67.0 \\
\hline Sensitivity ratio $\ldots \ldots \ldots \ldots \ldots$ & 14 & 2.8 & 5 & 2 & 2.5 & 1.0 \\
\hline
\end{tabular}

\footnotetext{
${ }^{1}$ Not applicable.
}

Table 4. Summary of engineering-soils properties of F.III, Bootlegger Cove Formation, Government Hill area

[nd, not determined]

\begin{tabular}{|c|c|c|c|c|c|c|}
\hline & $\begin{array}{c}\text { Sample } \\
\text { array } \\
\text { size } \\
n\end{array}$ & $\begin{array}{l}\text { Mean } \\
\text { value } \\
\bar{X}\end{array}$ & $\begin{array}{l}\text { Maxi- } \\
\text { mum } \\
\text { value } \\
\text { of } \\
\text { array } \\
X_{\max }\end{array}$ & $\begin{array}{l}\text { Mini- } \\
\text { mum } \\
\text { value } \\
\text { of } \\
\text { array } \\
X_{\min }\end{array}$ & $\begin{array}{c}\text { Median } \\
\text { value } \\
\text { Md }\end{array}$ & $\begin{array}{c}\text { Standard } \\
\text { deviation } \\
\sigma_{x}\end{array}$ \\
\hline Thickness (meters). & 16 & 6.6 & 20.7 & 0.7 & 5.9 & $\left({ }^{1}\right)$ \\
\hline Moisture content (percent) . . . . . . . & 57 & 29.8 & 45 & 22 & 30 & 5.0 \\
\hline Plastic limit (percent) $\ldots \ldots \ldots \ldots$ & 37 & 22.0 & 25 & 17 & 22 & 1.9 \\
\hline Liquid limit (percent) $\ldots \ldots \ldots \ldots$ & 38 & 28.3 & 37 & 22 & 27 & 3.8 \\
\hline Plasticity index $\ldots \ldots \ldots \ldots \ldots$ & 36 & 7.0 & 13 & 3 & 7 & 2.5 \\
\hline Standard penetration. . . . . . . . . & 32 & 42 & 80 & 1 & nd & nd \\
\hline Shear strength $\left(\mathrm{kN} / \mathrm{m}^{2}\right) \ldots \ldots \ldots \ldots$ & 54 & 49.8 & 95.8 & 23.9 & 47.9 & 12.4 \\
\hline Compressive strength $\left(\mathrm{kN} / \mathrm{m}^{2}\right) \ldots \ldots \ldots$ & 24 & 88.1 & 134.1 & 68.0 & 86.2 & 15.3 \\
\hline Sensitivity ratio $\ldots \ldots \ldots \ldots \ldots$ & 63 & 19.7 & 40 & 9 & 18 & 6.6 \\
\hline
\end{tabular}

${ }^{1}$ Not applicable.

the relation between natural moisture content and the liquid limit, as calculated by the equation

$$
L i=\left(W_{n}-W_{p}\right) /\left(W_{l}-W_{p}\right)
$$

where $W_{n}, W_{p}$, and $W_{l}$ are averages of all test data for a given unit. F.III alone has a mean value of $L i$ greater than 1.0 .

Shear strength values $(\mathbf{S})$ were obtained from uncon- solidated, undrained triaxial compression and from laboratory vane-shear tests. Considerable caution was exercised in the selection of shear strength values for this study to minimize variability in the data due to possible problems in laboratory procedures, sample handling, and the accuracy of the laboratory apparatus used. The authors have attempted to include only values for test samples retaining natural moisture content. 
Table 5. Summary of engineering-soils properties of F.IV, Bootlegger Cove Formation, Government Hill area

[nd, not determined]

\begin{tabular}{|c|c|c|c|c|c|c|}
\hline & $\begin{array}{c}\text { Sample } \\
\text { array } \\
\text { size } \\
n\end{array}$ & $\begin{array}{l}\text { Mean } \\
\text { value } \\
\qquad \bar{x}\end{array}$ & $\begin{array}{l}\text { Maxi- } \\
\text { mum } \\
\text { value } \\
\text { of } \\
\text { array } \\
X_{\max }\end{array}$ & $\begin{array}{l}\text { Mini- } \\
\text { mum } \\
\text { value } \\
\text { of } \\
\text { array } \\
X_{\min }\end{array}$ & $\begin{array}{c}\text { Median } \\
\text { value } \\
\text { Md }\end{array}$ & $\begin{array}{c}\text { Standard } \\
\text { deviation } \\
\sigma_{x}\end{array}$ \\
\hline Thickness (meters) . . . . . . . . . & 53 & 8.2 & $>56.1$ & 1.6 & 7.2 & $\left({ }^{1}\right)$ \\
\hline Moisture content (percent) . . . . . . . & 61 & 28.0 & 36.9 & 18 & 28 & 3.8 \\
\hline Plastic limit (percent) $\ldots \ldots \ldots \ldots$ & 26 & 20.5 & 26 & 13 & 22 & 4.0 \\
\hline Liquid limit (percent) $\ldots \ldots \ldots \ldots$ & 37 & 34.8 & 45 & 20 & 35 & 6.7 \\
\hline Plasticity index $\ldots \ldots \ldots \ldots \ldots$ & 36 & 16 & 27 & 6 & 24 & 6.2 \\
\hline Standard penetration. . . . . . . . . . & 71 & 22 & 100 & 3 & nd & nd \\
\hline Shear strength $\left(\mathrm{kN} / \mathrm{m}^{2}\right) \ldots \ldots \ldots \ldots$ & 57 & 66.1 & 114.9 & 19.2 & 68.9 & 21.1 \\
\hline Compressive strength $\left(\mathrm{kN} / \mathrm{m}^{2}\right) \ldots \ldots \ldots$ & 26 & 111.1 & 210.7 & 40.2 & 114.0 & 33.5 \\
\hline Sensitivity ratio $\ldots \ldots \ldots \ldots \ldots$ & 37 & 6.1 & 21 & 1 & 5 & 4.3 \\
\hline
\end{tabular}

${ }^{1}$ Not applicable.

Table 6. Summary of engineering-soils properties of F.V, Bootlegger Cove Formation, Government Hill area

[Leaders (--) indicate that in three of the five cases, F.V occurred at bottom of hole; nd, not determined]

\begin{tabular}{|c|c|c|c|c|c|c|}
\hline & $\begin{array}{c}\text { Sample } \\
\text { array } \\
\text { size } \\
n\end{array}$ & $\begin{array}{l}\text { Mean } \\
\text { value } \\
\bar{x}\end{array}$ & $\begin{array}{c}\text { Maxi- } \\
\text { mum } \\
\text { value } \\
\text { of } \\
\text { array } \\
X_{\max }\end{array}$ & $\begin{array}{c}\text { Mini- } \\
\text { mum } \\
\text { value } \\
\text { of } \\
\text { array } \\
X_{\min }\end{array}$ & $\begin{array}{c}\text { Median } \\
\text { value } \\
\text { Md }\end{array}$ & $\begin{array}{c}\text { Standard } \\
\text { deviation } \\
\sigma_{x}\end{array}$ \\
\hline$\ldots \ldots \ldots \ldots \ldots \ldots$ & 5 & -- & $>9.5$ & 2.6 & -- & $\left({ }^{1}\right)$ \\
\hline Moisture content (percent) . . . . . . . & 16 & 28.4 & 37 & 8 & 28 & 6.4 \\
\hline Plastic limit (percent) $\ldots \ldots \ldots \ldots$ & 10 & 22.2 & 25 & 28 & 23 & 2.4 \\
\hline Liquid limit (percent) $\ldots \ldots \ldots \ldots$ & 10 & 36.9 & 41 & 29 & 37 & 3.8 \\
\hline Plasticity index $\ldots \ldots \ldots \ldots \ldots$ & 10 & 14.7 & 18 & 9 & 15 & 2.7 \\
\hline Standard penetration. . . . & 12 & 18 & 50 & 4 & nd & nd \\
\hline Shear strength $\left(\mathrm{kN} / \mathrm{m}^{2}\right) \ldots \ldots$ & 6 & 104.4 & 124.5 & 80.4 & 95.8 & 17.2 \\
\hline Compressive strength $\left(\mathrm{kN} / \mathrm{m}^{2}\right) \ldots \ldots \ldots$ & 11 & 182.9 & 268.1 & 80.4 & 183.9 & 54.6 \\
\hline Sensitivity ratio $\ldots \ldots \ldots \ldots \ldots$ & 3 & 4.1 & 4.4 & 3.7 & 4.2 & .5 \\
\hline
\end{tabular}

${ }^{1}$ Not applicable.

In the ideal case, the unconfined compressive strength, $q u$, should equal twice the shear strength of the same sample under undrained conditions. However, due to differences in testing conditions as well as associated errors and approximations consequential to the testing procedures, the $q u$ values do not generally agree with the ideal case (fig. 7), and are therefore reported separately in tables $2-8$. For this study, only values of $q u$ obtained by laboratory testing in an undrained and unconfined compression apparatus are reported. We have refrained from using pocket penetrometer values in this report because those data lack reliability control for specific values, although such values may have considerable merit as indicators of general engineering stratigraphic trends.

The mean values of shear strength for the predominant materials of F.I and F.III are nearly equal at about 
Table 7. Summary of engineering-soils properties of F.VI, Bootlegger Cove Formation, Government Hill area

[nd, not determined; nc, noncohesive. F.VI is dominantly sand; for plastic limit, liquid limit, plasticity index, Atterberg limits obtained on interbedded silts and clays]

\begin{tabular}{|c|c|c|c|c|c|c|}
\hline & $\begin{array}{c}\text { Sample } \\
\text { array } \\
\text { size } \\
n\end{array}$ & $\begin{array}{l}\text { Mean } \\
\text { value } \\
\bar{X}\end{array}$ & $\begin{array}{l}\text { Maxi- } \\
\text { mum } \\
\text { value } \\
\text { of } \\
\text { array } \\
X_{\max }\end{array}$ & $\begin{array}{l}\text { Mini- } \\
\text { mum } \\
\text { value } \\
\text { of } \\
\text { array } \\
X_{\min }\end{array}$ & $\begin{array}{c}\text { Median } \\
\text { value } \\
\text { Md }\end{array}$ & $\begin{array}{c}\text { Standard } \\
\text { deviation } \\
\sigma_{x}\end{array}$ \\
\hline Thickness (meters) . . . . . . . . . & 7 & 2.3 & 4.9 & 1.3 & 2.0 & $\left({ }^{l}\right)$ \\
\hline Moisture content (percent) . . . . . . . & 22 & 25.0 & 37 & 18 & 25 & 3.0 \\
\hline Plastic limit (percent) $\ldots \ldots \ldots \ldots$ & 5 & 22.4 & 25 & 18 & 23 & 2.4 \\
\hline Liquid limit (percent) $\ldots \ldots \ldots \ldots$ & 5 & 32.8 & 45 & 27 & 30 & 6.6 \\
\hline Plasticity index $\ldots \ldots \ldots \ldots \ldots$ & 5 & 10.4 & 21 & 5 & 9 & 5.7 \\
\hline Standard penetration. . . . & 5 & 27.6 & 50 & 8 & nd & nd \\
\hline Shear strength $\left(\mathrm{kN} / \mathrm{m}^{2}\right) \ldots \ldots \ldots$ & 6 & 58.4 & 62.2 & 47.9 & 59.4 & 4.8 \\
\hline Compressive strength $\left(\mathrm{kN} / \mathrm{m}^{2}\right) \ldots \ldots \ldots$ & 6 & 126.4 & 164.7 & 101.5 & 108.2 & 26.8 \\
\hline Sensitivity ratio $\ldots \ldots \ldots \ldots \ldots$ & nc & nc & nc & nc & nc & $\mathrm{nc}$ \\
\hline
\end{tabular}

\footnotetext{
${ }^{1}$ Not applicable.
}

Table 8. Summary of engineering-soils properties of F.VII, Bootlegger Cove Formation, Government Hill area

[nd, not determined; np, nonplastic; nc, noncohesive; nv, nonviscous]

\begin{tabular}{|c|c|c|c|c|c|c|}
\hline & $\begin{array}{c}\text { Sample } \\
\text { array } \\
\text { size } \\
n\end{array}$ & $\begin{array}{l}\text { Mean } \\
\text { value } \\
\frac{x}{x}\end{array}$ & $\begin{array}{l}\text { Maxi- } \\
\text { mum } \\
\text { value } \\
\text { of } \\
\text { array } \\
X_{\max }\end{array}$ & $\begin{array}{l}\text { Mini- } \\
\text { mum } \\
\text { value } \\
\text { of } \\
\text { array } \\
X_{\text {min }}\end{array}$ & $\begin{array}{c}\text { Median } \\
\text { value } \\
\text { Md }\end{array}$ & $\begin{array}{c}\text { Standard } \\
\text { deviation } \\
\sigma_{x}\end{array}$ \\
\hline Thickness (meters). . . . . . . . . . . & 11 & 5.6 & 19.0 & 0.7 & 4.3 & $\left({ }^{1}\right)$ \\
\hline Moisture content (percent) . . . . . . . & 8 & 20.4 & 29 & 14 & 20 & 4.3 \\
\hline Plastic limit (percent) $\ldots \ldots \ldots \ldots \ldots$ & $\mathrm{np}$ & $\mathrm{np}$ & np & $\mathrm{np}$ & np & np \\
\hline Liquid limit (percent) $\ldots \ldots \ldots \ldots \ldots$ & nv & nv & nv & nv & nv & nv \\
\hline Plasticity index $\ldots \ldots \ldots \ldots \ldots$ & np & np & $\mathrm{np}$ & $\mathrm{np}$ & np & np \\
\hline Standard penetration. . . . . . . . . & 17 & 34 & 60 & 12 & nd & nd \\
\hline Shear strength $\left(\mathrm{kN} / \mathrm{m}^{2}\right) \ldots \ldots \ldots \ldots$ & nd & nd & nd & nd & nd & nd \\
\hline Compressive strength $\left(\mathrm{kN} / \mathrm{m}^{2}\right) \ldots \ldots$ & nd & nd & nd & nd & nd & nd \\
\hline Sensitivity ratio $\ldots \ldots \ldots \ldots \ldots$ & nc & nc & nc & $\mathrm{nc}$ & nc & nc \\
\hline
\end{tabular}

\section{${ }^{1}$ Not applicable.}

$50 \mathrm{kN} / \mathrm{m}^{2}$, but differ markedly in unconfined compressive strength: F.I has a mean $q u=162 \mathrm{kN} / \mathrm{m}^{2}$, and F.III has a mean $q u=88 \mathrm{kN} / \mathrm{m}^{2}$ (tables 2 and 4 , fig. 8). This may reflect a difference in depositional history and postdepositional consolidation dependent on the original soil structure and subsequent loading.

The predominant materials of each of the five cohesive facies are essentially the same in mineralogy, clast shape, and size distribution, with the exception of F.I, which is primarily composed of clay-size particles. We believe that the variations in shear- and compressivestrength characteristics of each facies are significantly influenced by primary microstructures in the soil fabric, and by amount and distribution of secondary constituents, such as sand. Table 6 shows that the unconfined compressive strength of F.V is significantly higher than that of the 


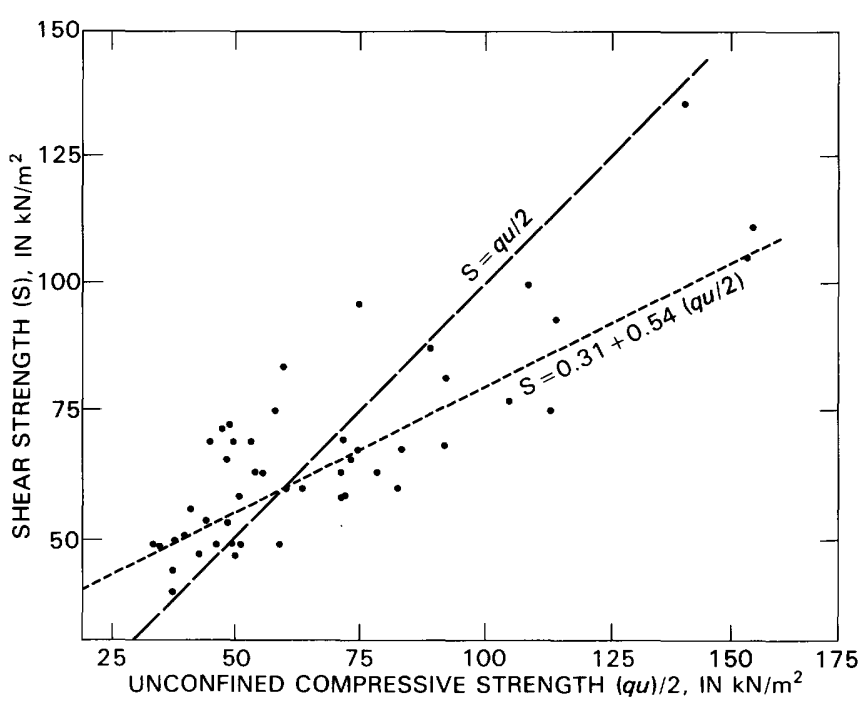

Figure 7. Correlation of shear strength and unconfined compressive strength for samples of cohesive facies ( $F . I$ to F.V) of the Bootlegger Cove Formation, Government Hill area. Long-dashed line, ideal case; short-dashed line based upon a least-square linear-regression analysis of plotted data points.

other facies. This strength is believed to be, in large part, due to (1) a compact texture which is normally consolidated by the effective overburden pressure, (2) a wellgraded size distribution, and (3) coarse clasts acting as fabric binders. The uniform fine-grained texture and better packing probably account for the slightly improved strength of F.II as compared to F.IV.

Although F.III alone shows pronounced sensitivity, all the cohesive facies show some degree of sensitivity. Generally, the data indicate that those soils with higher initial shear strength also have lower sensitivity ratios. In figure 9 , the mean undisturbed shear strength, $\overline{\mathrm{S}}$, is plotted against the mean sensitivity ratio, $\overline{\mathrm{Sr}}$, for each facies. A general trend of diminishing strength retention emerges, with F.V having the highest value, whereas the clay facies (F.I) and sensitive facies (F.III) plot divergently at the base of the graph, again suggesting a significant difference in soil fabric between these two facies.

Finally, a comparison is made of mean liquidity indices and mean sensitivity ratios for the predominant material of the facies (fig. 10). The mean curve for data points given by Shannon and Wilson, Inc. (1964) for the Fourth Avenue and Turnagain Heights landslides of 1964 is plotted for comparison. Sensitivities generally increase dramatically with liquidity indices greater than one. F.III plots high on the Shannon and Wilson line, and the other facies cluster about the base of the curve.

In summary, although the five cohesive soil facies are primarily distinguished by textural differences, they can also be distinguished by subtle differences in strength. As expected, F.III is quite distinct from the other four facies. The strength of F.V is slightly higher than that

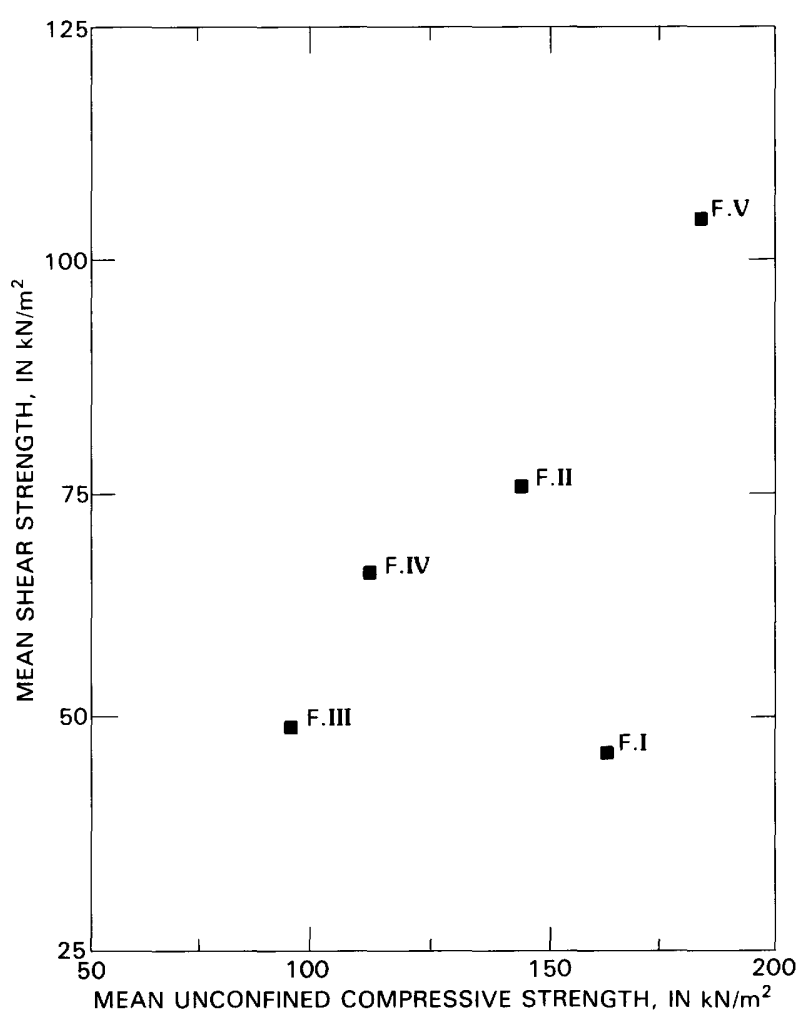

Figure 8. Correlation of mean shear strength and mean compressive strength, for cohesive facies ( $F .1$ to F.V) of the Bootlegger Cove Formation, Government Hill area.

of any of the other facies, both initially and after remolding, probably due to the presence of sand and gravel, as well as to a higher degree of consolidation. F.II and F.IV are very similar to each other based upon laboratory testing, and the distinction between these facies has primarily geologic rather than engineering significance. If the standard geotechnical measurements reported here can be assumed to give approximations of relative static and dynamic behavior, then F.II and F.IV should both behave in a similar manner. Even though the initial shear strength of the clay of F.I is nearly identical to that of the clayey silt of F.III, mean sensitivity of F.I is less than half that of F.III. This may signify a fundamental difference in soil structure between the two facies. It is believed that, should in-place remolding of F.III occur, ultimately this facies would have close affinity to F.II, and the two may basically differ only in their strain histories.

\section{Post-Bootlegger Cove Formation Glaciofluvial Deposits}

In the eastern half of the project area where the Bootlegger Cove Formation has not been subjected to Holocene erosion, the formation is overlain by well-stratified sands and gravels. Where exposed, the contact be- 


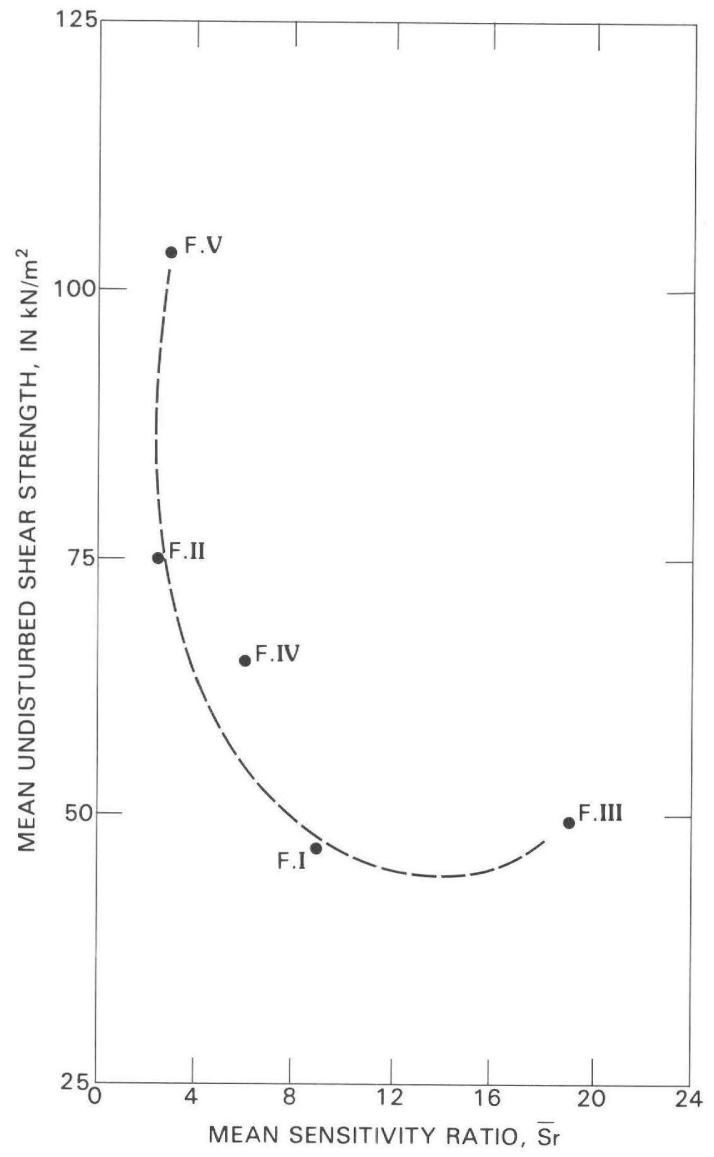

Figure 9. Correlation of mean undisturbed shear strength and mean sensitivity ratio for cohesive facies of the Bootlegger Cove Formation, Government Hill area. Note trend of line from overconsolidated dense facies (F.V) to normally consolidated low-strength facies (F.III).

tween these two units is normally defined by an abrupt transition from the Bootlegger Cove Formation to finely stratified beds of sand and gravel which exhibit a variety of sedimentary features characteristic of fluvial deposition, including crossbedding, cut-and-fill structures, graded bedding, and well-sorted planar beds of gravel (fig. 11). The sequence varies in thickness from less than $10 \mathrm{~m}$ in the southwest part of Government Hill to $26 \mathrm{~m}$ at the northern and eastern limits of our study area (Elmendorf Air Force Base). A series of four terraces constitute the geomorphic forms composed of this sand and gravel. These terraces lie directly outside the limit of the Elmendorf Moraine. We conclude that these deposits are indeed glaciofluvial deposits laid down directly in front of the Elmendorf Glacier, although the actual terrace morphology seems more likely erosional than depositional.

The clasts are subrounded to well rounded and moderately to loosely packed, and both porosity and permeability are high. As a result, ground water accumulates at the base of the unit forming a perched aquifer above

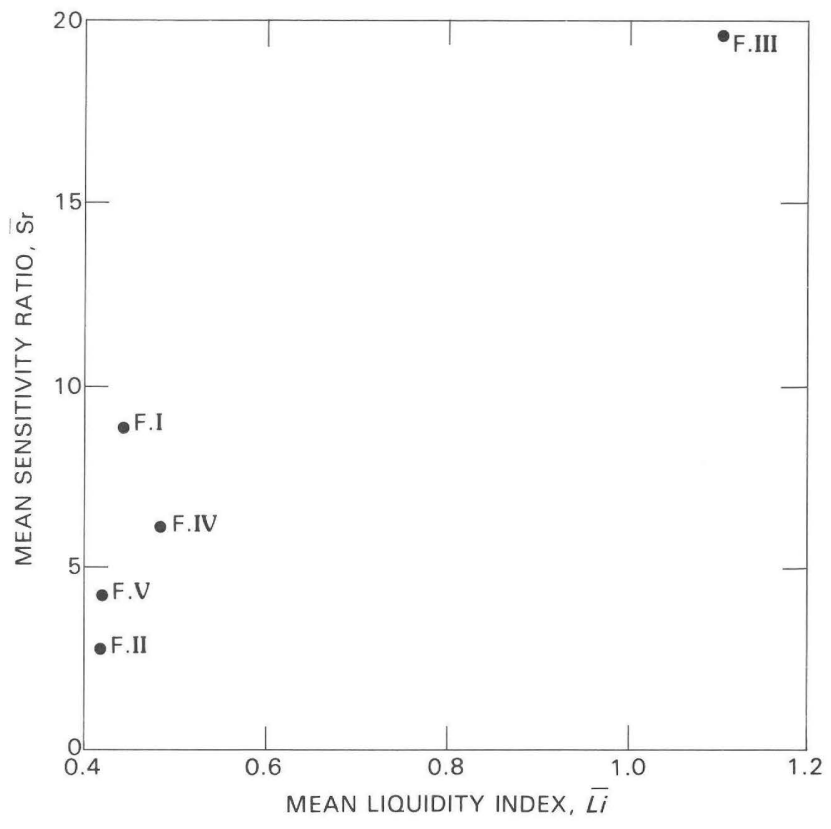

Figure 10. Correlation of mean sensitivity ratio and mean liquidity index for the five cohesive facies of the Bootlegger Cove Formation.

the Bootlegger Cove Formation which, in turn, behaves as a low-permeability bed. This perched-aquifer relation generally assures that intermediate sand, if present, is saturated, which is significant in evaluating liquefaction potential. Due to the topography on the upper surface of the Bootlegger Cove Formation (Updike, 1986), the drainage within this perched aquifer is directed toward topographic lows on the Bootlegger Cove superface. This drainage pattern strongly affects the slope stability of the upper part of the Bootlegger Cove Formation by assuring saturation throughout the sand facies (F.VI and F.VII), a prime factor in liquefaction susceptibility. The drainage pattern also causes the natural moisture content to exceed the liquid limit in F.III.

\section{Tidal Flat and Tidal Marsh Deposits}

Seaward from the base of bluffs and associated landslides are sediments which have been deposited subsequent to sea level planation of the Bootlegger Cove Formation. The distinction between tidal flat and tidal marsh deposits is made on the basis of respective dominance of inorganic clastic sediments versus organic deposits. Although the two units are intercalated in the subsurface, the tidal marsh deposits generally overlie the tidal flat units landward from the high tide strandline. The borehole data indicate that the combined units form a seawardthickening wedge, laid down on the beveled superface of the Bootlegger Cove Formation. The surface of these deposits ranges in elevations from a maximum of about 9.7 
$\mathrm{m}$ above sea level to below sea level, sloping uniformly from the landward limit to high tide strandline at less than $0.5^{\circ}$ and then increasing in surface slope to greater than $2.0^{\circ}$ to beyond mean low sea level.

The tidal flat unit comprises sediments with distinct bedding which vary in stratigraphic thickness and elevation from one borehole to the next but when examined collectively exhibit a sequential record as shown in figure 12. If one examines modern tidal flat clastic deposition in upper Cook Inlet, some generalized analogies can be drawn for environments of deposition. The coarse clastic deposits (gravels, sandy gravels) are emergent units, that is, deposited at or above high strandline. Silty clay, clayey silt, silty fine sand, and sandy silt are more typical of the intertidal zone and seaward from this zone, with the minor amounts of coarser sand and gravel being introduced by slope wash from behind strandline and by tidal ice rafting. The rather limited deposits of clays containing minor amounts of silt and fine sand represent restricted depositional depressions, either within the high intertidal zone or as backwater depressions of the coastal flats. Although it is tempting to purport that the composite sequence represents finite tectonic or eustatic sea level changes of Cook Inlet, the map area is far too limited to make such deductions. At this point we conclude that, subsequent to planation of the Bootlegger Cove Formation, tidal inlet clastic deposits several tens of meters thick have accumulated, that this sequence has been subjected to incremental burial by similar deposits, and that, because the older sediments of the section are several tens of meters below modern MSL, either the depositional basin has been subsiding or sea level has been rising, or both.

Several logs indicate qualitatively the degree of consolidation by terms such as loose, compact, dense, and very dense. Again, by assimilating the data from various holes, one can conclude that the sequence appears to be normally consolidated from top to bottom (fig. 12). This undoubtedly reflects the progressive loading of the older sediments but may also denote tidal energies imparted to

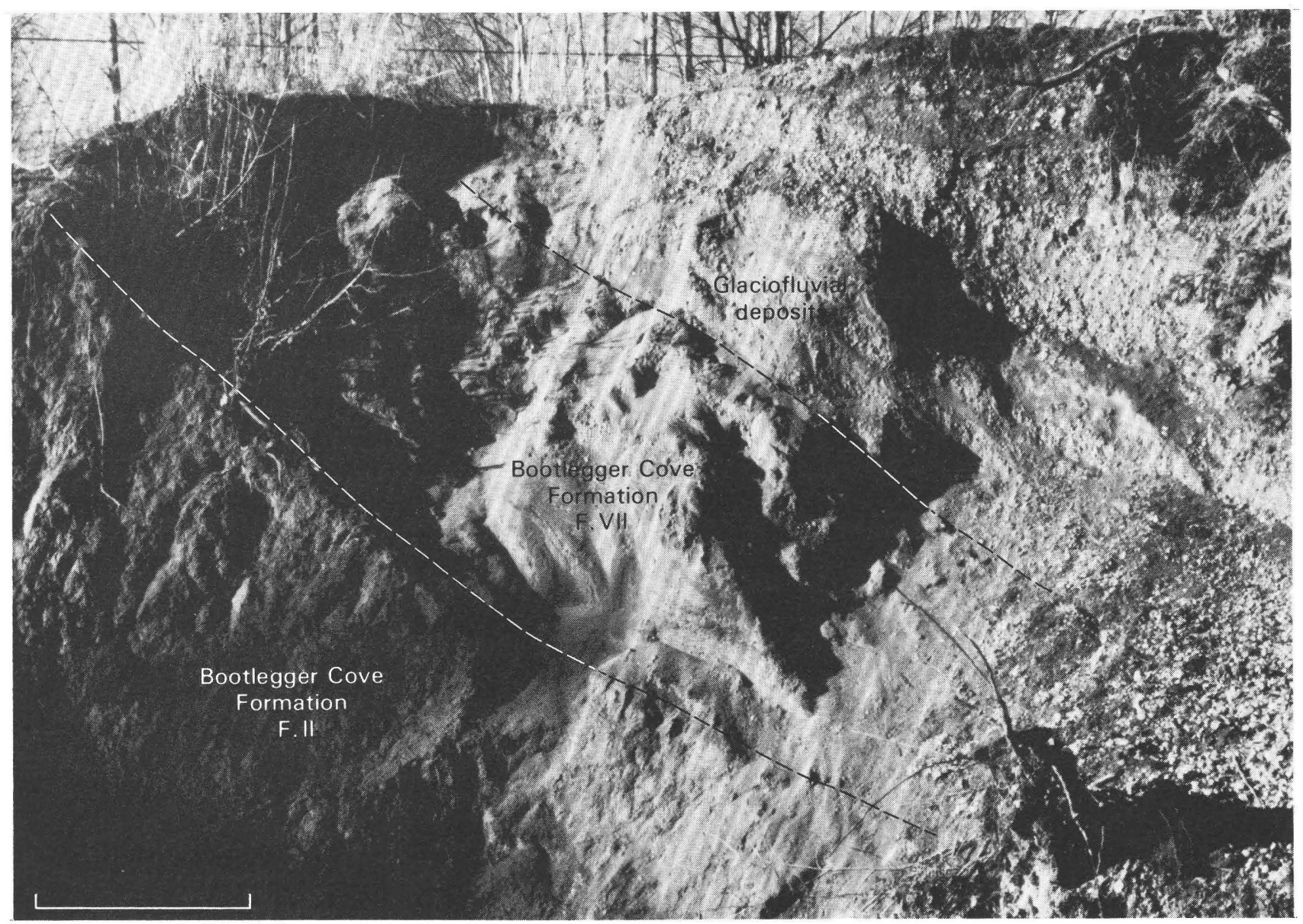

Figure 11. Exposure in landslide block, in gully west of Elmendorf Air Force Base, showing glaciofluvial deposits of the Naptowne glaciation of Karlstrom (1964) overlying the Bootlegger Cove Formation (lower left corner). Note apparent dip of units to lower right (east) due to slide dislocation. Photograph by R. G. Updike, 1980; bar scale (lower left) is approximately $1 \mathrm{~m}$ long. 


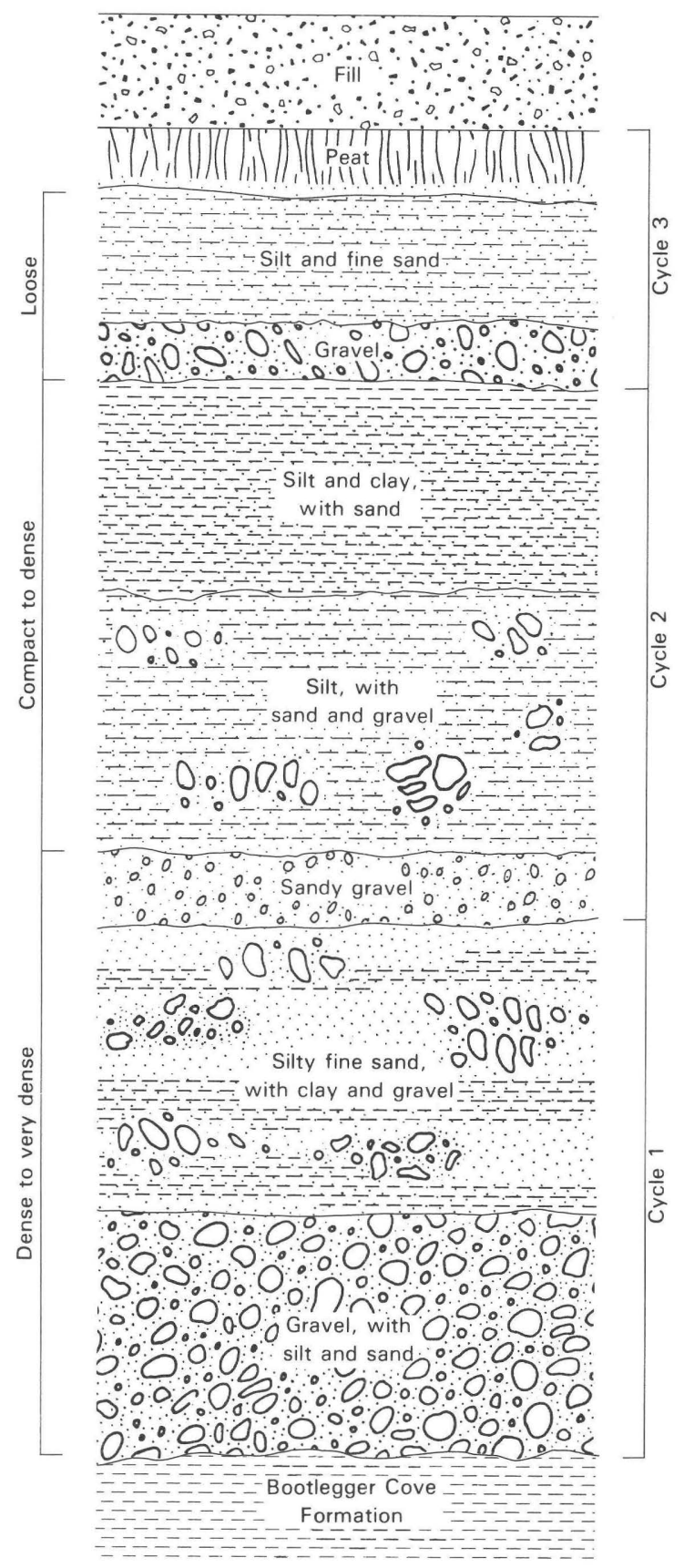

Figure 12. Idealized stratigraphic sequence of tidal flat deposits based upon a composite of borehole logs at several sites, Government Hill area. Relative thicknesses of individual layers are accurate, although variation in thickness will occur at different locations, from a few to several tens of meters. Three cycles of deposition of clastic tidal marine sediments are recorded. Each cycle is initiated with deposition of coarse sediment (gravel) and ends with silt and fine sand. Each cycle is less compacted than the cycle below it, which we believe is due to overburden pressure and increasing age (late Holocene) from cycle 3 to cycle 1 . the older sediments different from modern energy regimes, causing a denser packing and, in the case of finer sediments, better sorting factors. The increase in consolidation with increasing depth reduces concerns for tidal flat liquefaction but certainly does not remove the potential. For example, at approximately modern low-tide elevation there exists, discontinuously, a gravelly sand and sandy gravel zone which is moderately loose, saturated, and overlain by as much as $10-20 \mathrm{~m}$ of finer tidal flat deposits, tidal marsh deposits, and fill, upon which buildings have been built. During the 1964 earthquake, numerous ground fissures, some slumping, and lateral spreading occurred in the tidal flat deposits. Although no serious damage resulted, the potential for more serious failures was demonstrated. The cracking may well have been the function of vertical acceleration causing consolidation, lateral shear along stratigraphic horizons, or, in the extreme case, limited liquefaction. No evidence (for example, sand boils, sand-filled fissures) has been recorded to document that liquefaction was responsible.

The tidal marsh deposits, as much as $4 \mathrm{~m}$ thick, are composed primarily of organic silts interbedded with lenses and beds of peat and fine sand. These deposits have formed landward from high tide line. Early photography of the coastal flats and 1940-1960 vertical aerial photography indicate that many of the areas now covered by fill were originally mantled by tidal marsh deposits. In some instances, the organic silt and peat zone was stripped away before the fill aggregate was spread; however, more often the fill was laid down directly on the organic silt layer. This can result in problems to structures placed over peat zones, such as pronounced amplification of some frequencies of seismic accelerations, development of permafrost, and ground settlement.

\section{Landslide Deposits}

Historic and prehistoric slope failures have been discussed at some length by Varnes (1969), who was particularly interested in the mechanics of slides associated with the Bootlegger Cove Formation. He recognized the regional extent of such failures, but actual mapping was outside the focus of his study (D. J. Varnes, oral commun., 1979). Our present project has found that numerous, presently inactive slides encompass most of the bluff line of Government Hill. Three types of failures have been distinguished: translatory slides, rotational slumps, and flows. In some instances, failure was initiated as one type and progressed into another type; for example, the Government Hill Elementary School slide (1964) consisted of rotational blocks, which progressed into successive slurry flows at the toe of the failing mass. Elsewhere, the mechanism is simple; for example, a series of active, 
slow-moving rotational blocks occur along the bluffs west of Elmendorf Air Force Base. In a prominent gully in that area, excellent exposures have been stream-cut normal to the long axis of large slide blocks, again showing simple rotational failure in coherent blocks (fig. 11). An apparently unique failure occurred in the area of what is now the Chevron Petroleum storage-tank farm. Varnes (1969) recognized and described this unusual (and now totally obscured) landform, which exhibited a low-gradient, lobate form extending from the base of the thenexisting bluff line (herein referred to as the Chevron Tank Farm slide, fig. 13). We intuitively favor a flow origin, but because of the antiquity of the mass movement and subsequent cultural modification, we cannot know for sure. A prehistoric slide near the 1964 Government Hill School slide appears to have been a translatory slide similar to the 1964 "L" Street slide in downtown Anchorage, but having an additional 5-m vertical component of movement.

We have mapped individual landslide deposits (fig. 13) because, first, the deposits are distinctly different in composition from the parent soils units due to oftenchaotic mixing of sediments and disruption of stratigraphy. Second, distinguishing areal extent, type, and relative age of slides aids in potential hazard assessment. Finally, we can better evaluate seismically induced failure

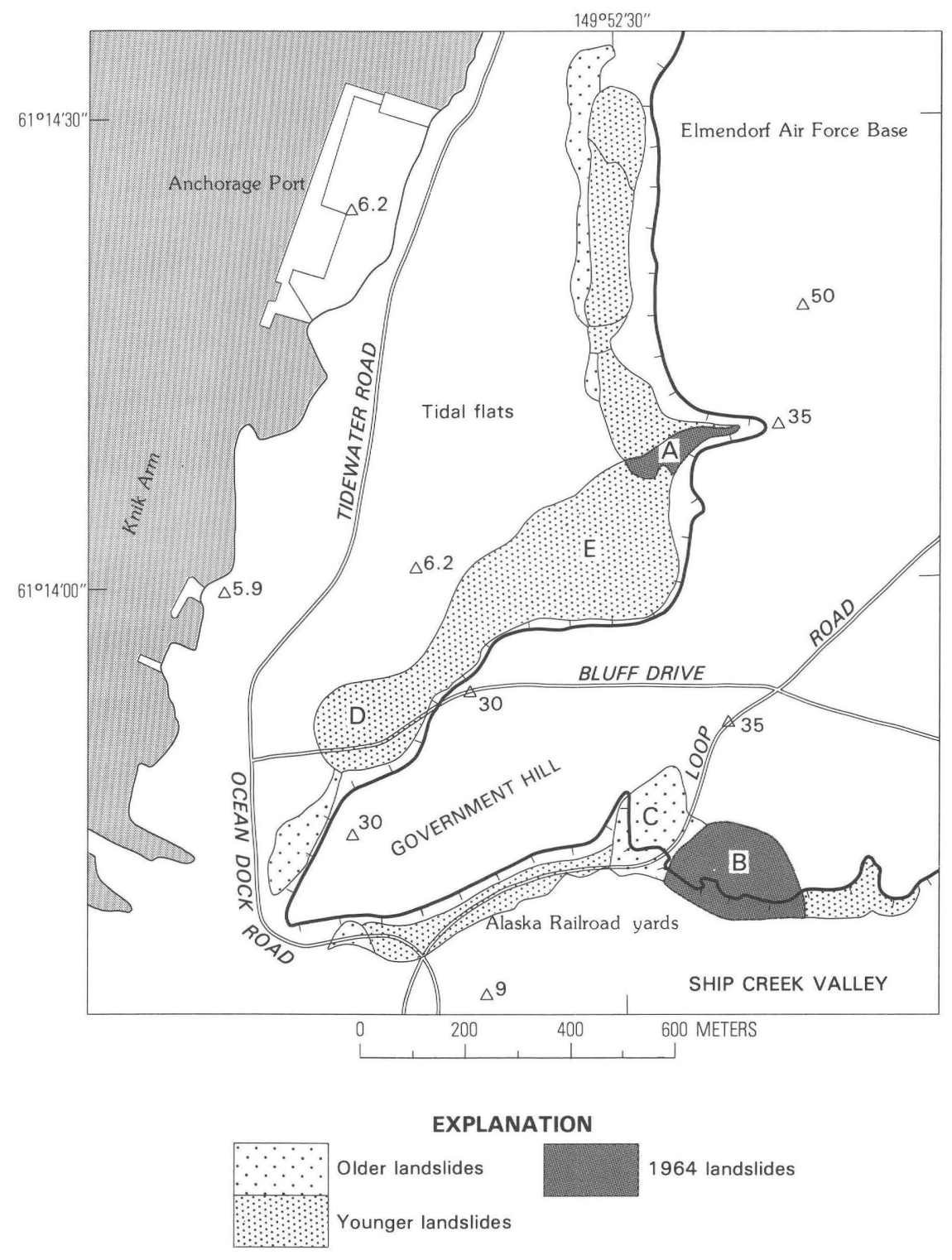

Figure 13. Distribution of landslides in Government Hill area, as discussed in text. A, Elmendorf; B, Government Hill Elementary School; C, Curling Club; D, Chevron Tank Farm; E, P.O.L. Tank Farm. Approximate spot elevations shown, in meters. 
potential of engineering geologic facies of the Bootlegger Cove Formation if we examine past behavior. The mapping units have been distinguished on the basis of relative age of the individual slide masses, qualitatively referred to in order of decreasing age as "older," younger," and "1964 earthquake." This classification takes into account modification of slide morphology (for example, erosion of scarps, rounding of ridges, filling of troughs, erosion or burial of the toe), vegetation and soil development, crosscutting and superimposed relations between slides, and historic written and photographic records.

"Older" slides are characterized by (1) highly modified to gently hummocky surfaces, (2) obscure slide toes often gradational to tidal flat or tidal marsh units, (3) heavy vegetation and continuous soil cover, and, often, (4) being overlain by "younger" slides. In contrast, the "younger" slides still exhibit ridge-and-trough topography, ponded surface water, pioneer vegetation, and discontinuous soils with breaks exposing sand gravels and (or) the Bootlegger Cove Formation; and they generally occur directly downslope from the identifiable slide scarp. In particularly slide-prone areas, multiple "younger" slide units can be superimposed on each other. The two 1964 slides (herein named Elmendorf and Government Hill Elementary School (figs. 13, 14)) are well documented in the literature (Shannon and Wilson, Inc., 1964; Varnes,

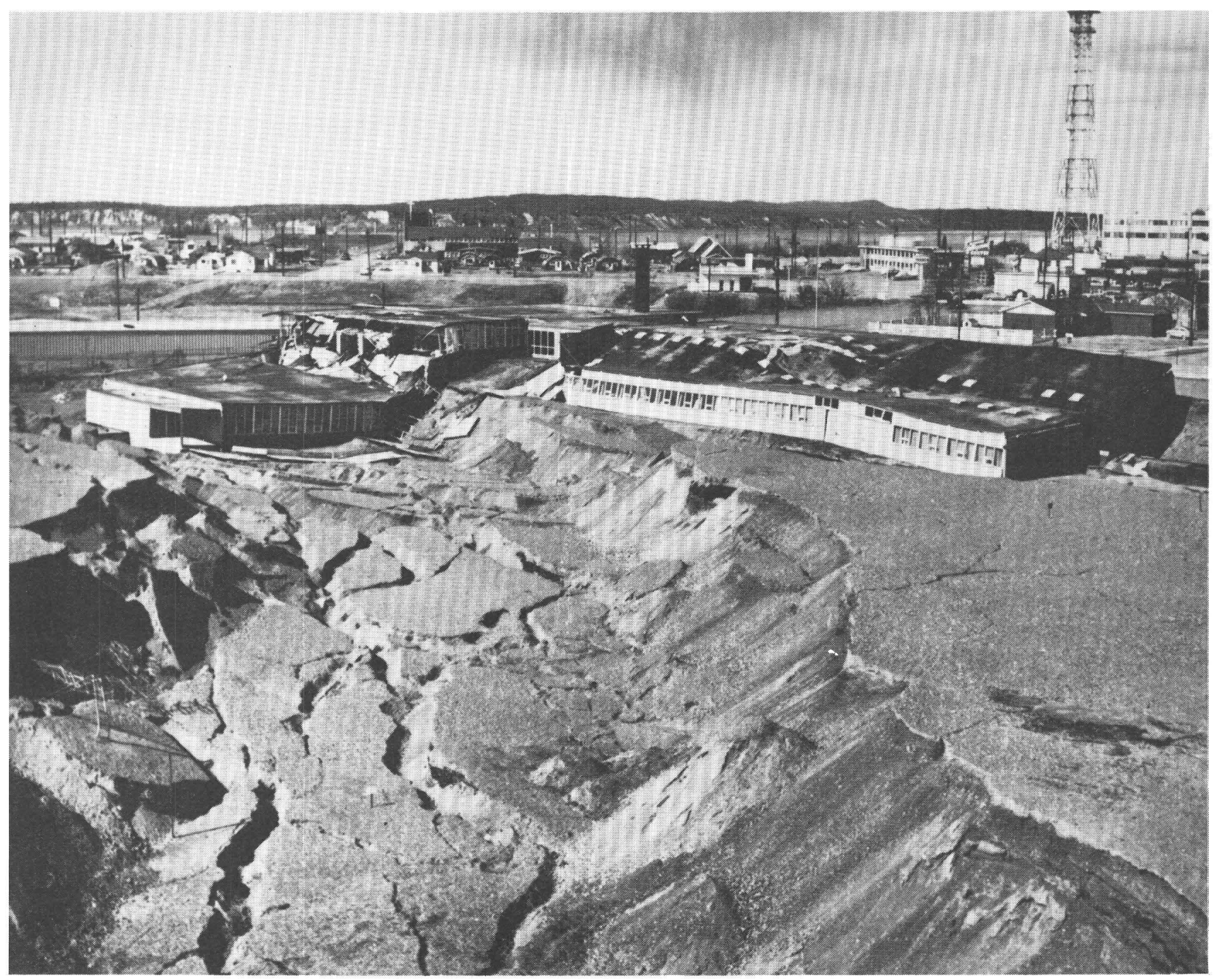

Figure 14. Government Hill Elementary School landslide, immediately after the March 27, 1964, earthquake. View looking west; slide moved from right to left in photograph view. Note graben-like structures in foreground which vertically displaced south wing of the school. An older slide (Curling Club slide) visible between school and houses in background. Photograph provided with permission of the Anchorage Historical and Fine Arts Museum (No. B77.118.121) from negative 398 taken by U.S. Corps of Engineers. 
1969). In the subsequent 20 years, these slides have begun to assume many of the features used as criteria for the "younger" slides. In addition to the two primary slides resulting from the 1964 earthquake, a considerable amount of ground cracking and high-angle slip occurred in the preexistent landslides. Although partially obscured by vegetation on these older units, cracks and scarps can readily be distinguished on the Mohawk aerial photograph flown on April 4, 1964. Although cracks were noted at numerous locations (see Varnes, 1969, fig. 15), among the most noteworthy were east of the Government Hill Elementary School slide, west of the Cherry Hill Apartments, north of the buried P.O.L. tanks, and east of Ocean Dock Road behind the Independent Lumber Company warehouse. In each instance, vertical slip occurred along scarps parallel to the topographic contours of the original slide surface and, in most instances, developed along preexisting lineaments within the slide mass. The Elmendorf landslide was similar to the Native Hospital slide (see Shannon and Wilson, Inc., 1964) in that both consisted in part of an old landslide, and in part of a newly activated block. At the Elmendorf slide, the newly detached block moved in compression against the older slide, resulting in compression ridges, again parallel to topographic contours. Some small post-1964 slides have been identified, presumably resultant from a seismic mass wasting. Adjacent ground cracks suggest that slow, progressive, small-scale slump failures are developing along bluffs north from West Bluff Road.

\section{Fluvial Deposits Associated with Modern Drainage}

The southern segment of the study area is bounded by the flood plain of Ship Creek, a stream that drains westward from the Chugach Mountains. After the stream issues from the mountains, only its lower $4-5 \mathrm{~km}$ has a well-defined flood plain. Along its route, the stream erodes and retransports silt, sand, and gravel associated with late Quaternary sedimentary units, as well as bedrock in the headwaters region. The valley geometry indicates that the hydrologic regime of the stream was far more dynamic in the past than at present. Anchorage and Government Hill have average upland elevations of about 40 $\mathrm{m}$ above MSL. The broad valley of Ship Creek has eroded to an elevation of 3-5 $\mathrm{m}$ above modern MSL. This morphology may reflect the drainageway of an ancestral Eagle River that flowed south of the Elmendorf Moraine. Subsequent to this period of downcutting, the stream has aggraded 5-7 m of well-stratified silt, sand, and gravel over the erosion surface developed on the Bootlegger Cove Formation. Boreholes indicate that these Holocene sediments thin north and south toward the bluffs at the margins of the valley. In general, silty sand and silt units, with lenses of coarser sand and gravel, occur near the surface, whereas with increasing depth stratified sand and gravel become more abundant. Most of the flood plain has been covered with man-related fill and (or) reworked fluvial sediments so that the original flood-plain morphology is obscure. Farther upstream, outside the project area, the stream shows evidence of active incision into the adjacent bluffs; however, in the mapped area such lateral planation is not exhibited. Adjacent to the present channel of Ship Creek, a subtle terrace surface is exposed at elevations of $3-5 \mathrm{~m}$ above MSL. This is interpreted as being an erosion surface on the Bootlegger Cove Formation where the Holocene fluvial sediments have been stripped away, exposing the older, more resistant formation. The depth of the water table varies from 1 to $7 \mathrm{~m}$, although the sediments are consistently near saturation throughout. During the 1964 earthquake, ground fissures developed along the Ship Creek drainage and in the intergradational zone between the tidal flat deposits and the fluvial sediments. The proximity to open bodies of water indicates that saturation and a subdued free face were prerequisites for most of the fissures that occurred in the fluvial sediments.

Farther north, at the mouth of the drainage flowing through a major gully from the uplands of Elmendorf Air Force Base, an alluvial fan has accumulated, presumably in Holocene time. The silt, sand, and gravel of this fan grade out into the tidal flat and tidal marsh deposits to the west. The three units are probably intercalated in the transition zone. The fan showed no evidence of disturbance during the 1964 earthquake.

All the fluvial deposits postdate both the Bootlegger Cove Formation and the glaciofluvial sediments but should be considered approximately contemporaneous with the tidal and landslide deposits.

\section{Man-related Fill Deposits}

Much of the flood plain of Ship Creek and the tidal flats from Ship Creek north to the municipal port are covered with $1-3 \mathrm{~m}$ of fill. This fill has been introduced into the area for at least the past 50 years. Generally, the fill is composed of aggregate excavated from nearby borrow pits in glaciofluvial deposits or in flood-plain deposits. Subsequent to the 1964 earthquake, larger quantities of landslide debris were hauled to the flood plain and tidal flats as part of the reconstruction and municipal development plan. This material (in many cases consisting exclusively of slide debris derived from the Bootlegger Cove Formation) was typically laid down in $0.5-$ to $1.0-\mathrm{m}$ layers, graded, artificially compacted, and subsequently covered with NFS (non-frost susceptible) aggregate, paving, or structural foundation materials. On the Ship Creek flood plain, the underlying fluvial sands and gravels have in many places been excavated, sometimes sorted or mixed with binding additives, and redistributed as site fill. 
Some of these borrow pits still remain on the flood plain. The fills that were in place at the time of the 1964 earthquake performed well, although ground fissures, spreading, or subsidence commonly developed along some buried topographic and geologic features, or as a result of underlying unit failure being expressed through the fill.

\section{SURFACE AND GROUND-WATER HYDROLOGY}

The static and dynamic properties of the soils at a site are directly influenced by water conditions at and adjacent to that site. Surface water may be operating independently, or as an extension of, the ground-water regime. The potential for surface water-ground water interaction is particularly obvious where aquifers are shallow and unconfined. Surface water occurs as open streams (Ship Creek and other minor spring-fed streams), ponds and marshes, and the tidal inlet (Knik Arm). Unconfined aquifers consist of the glaciofluvial deposits, tidal flat and tidal marsh deposits, and deposits associated with modern drainages. In each of these instances, the subsurface flow is expressed locally by surface-water bodies, but ultimately all flow is trending toward Ship Creek and Knik Arm. Within the areas mapped as landslide deposits, unconfined aquifers also occur but are often discontinuous, so that subsurface drainage often emerges as springs or seeps within, or at the toe of, slide masses. The unconfined ground-water table reasonably reflects the topography of the superface of the disrupted Bootlegger Cove Formation and, as a result, has a steep hydraulic gradient through the slide. Within the slide zone, the unconfined aquifer is thin, and saturated conditions will approximate the ground surface.

The connection of confined aquifers with surface drainages is less clear, although the ultimate flow direction is presumed to be toward Knik Arm. Two primary confined systems are in operation, aquifers beneath the Bootlegger Cove Formation, and F.VI and F.VII within the Bootlegger Cove Formation. The principal water-reservoir aquifers for Anchorage are confined beneath the Bootlegger Cove Formation; potentiometric surfaces commonly lie within 5 to $10 \mathrm{~m}$ of those of the unconfined aquifers above the formation (Barnwell and others, 1972). However, the characterization of vertical ground-water movement through the formation, which serves as an aquitard, is as yet unclear. Indeed, F.VI and F.VII, as well as adjacent cohesive soils of other facies, are saturated; but the gradient-flow directions are uncertain. We can argue strongly that the existence of the sensitive F.III is in part a function of in-place leaching of marine salts, which fill soil pores and act as connector assemblages in the open flocculated fabric of the undisturbed sediment (see Lambe and Whitman, 1979). It is not necessary for the fresh water to circulate through F.III, but the mere presence of percolating water in adjacent silt and sand lenses (such as F.VI and F. VII) can accomplish the leaching by diffusion (Torrance, 1974; Mitchell, 1976). That most of the F.II facies occurs at or above sea level lends further support to a leaching process, and may partly account for the mutual proximity of extensive landslide deposits and major surface streams and spring lines. The water-table data for 70 boreholes in the Government Hill area have been examined. Of these, only eight wells can confidently be said to penetrate into the confined aquifer beneath the Bootlegger Cove Formation. Although these wells indicate significant hydrostatic head, the data are too diverse in time, location, and method for recording to prove meaningful. Synoptic readings of screened wells fully penetrating the confined aquifer are necessary to give insight into ground-water movement, and these types of data have not been available.

The saturation of near-surface silts, sands, and gravelly sands in the Government Hill area raises concerns for their performance during seismic events. Particularly, the tidal flat deposits, some of the glaciofluvial deposits, and F.VI and F.VII of the Bootlegger Cove Formation are saturated, noncohesive, near-surface soils which could have potential for seismically induced liquefaction (see "Behavior of the engineering geologic units").

In addition to liquefaction, compaction of cohesionless soils can be a problem. The loose to moderately dense saturated silt and sand bodies in the tidal flat and lower Ship Creek flood-plain deposits are vulnerable to compaction during earthquakes. The fissures that occurred during the 1964 earthquake in tank farms, near port facilities, and in other areas of lower Ship Creek were likely caused by compaction in conjunction with minor lateral shifting. The potential for differential settlement due to compaction could also be a problem with sandy fill deposits.

The structure contour map of the superface of the Bootlegger Cove Formation (Updike, 1986) suggests that unconfined aquifer water in the glaciofluvial deposits above the formation would tend to drain southwest along a line between the military tank farms and the old Government Hill Elementary School. We suggest that the flow then divides, and we believe its water emerges along the free faces near the tank farms and Government Hill Elementary School (fig. 15). Springs do, in fact, emerge in the sands and gravels behind the Army P.O.L. tanks; in 1979 the authors observed new drains being installed to transport this significant discharge beneath the rehabilitated storage tanks at P.O.L. Further, notable spring discharge is presently occurring over the Government Hill School slide and has, since the 1964 event, eroded channels into the slide debris. The buried topography on the upper surface of the Bootlegger Cove Formation causes supraformational water to flow toward the Army tank farm (P.O.L.) and Government Hill Elementary School 
area, thereby increasing stability problems in these areas. This resultant ground-water flow causes shallow soils farther west to have below-saturation conditions, a situation that greatly improves the free-face stability near the point of Government Hill. The site improvement that has resulted from the Corps of Engineers' work with underdrains at the P.O.L. tanks should markedly improve stability in that area.

\section{BEHAVIOR OF THE ENGINEERING GEOLOGIC UNITS}

The intrinsic characteristics of the soils coupled with external factors such as seismicity, climate, and local hydrology can yield soil responses which site-specific inves- tigators should consider and anticipate. These potential responses could cause superficial damage to a facility, render it unusable, or destroy it altogether. Historic performance of soils in the Government Hill area has provided evidence for a variety of soil-foundation failures, from instantaneous (for example, the 1964 earthquake-induced Government Hill Elementary School landslide (fig. 14)) to imperceptibly slow but progressive (for example, the floor deformation of certain petroleum storage tanks). Although the extent of foundation problems is substantial and the evaluation of conditions at specific locations is beyond the scope of any single report, some general empirical assessments can be made based upon case histories in the vicinity as well as analogies drawn from outside Anchorage.

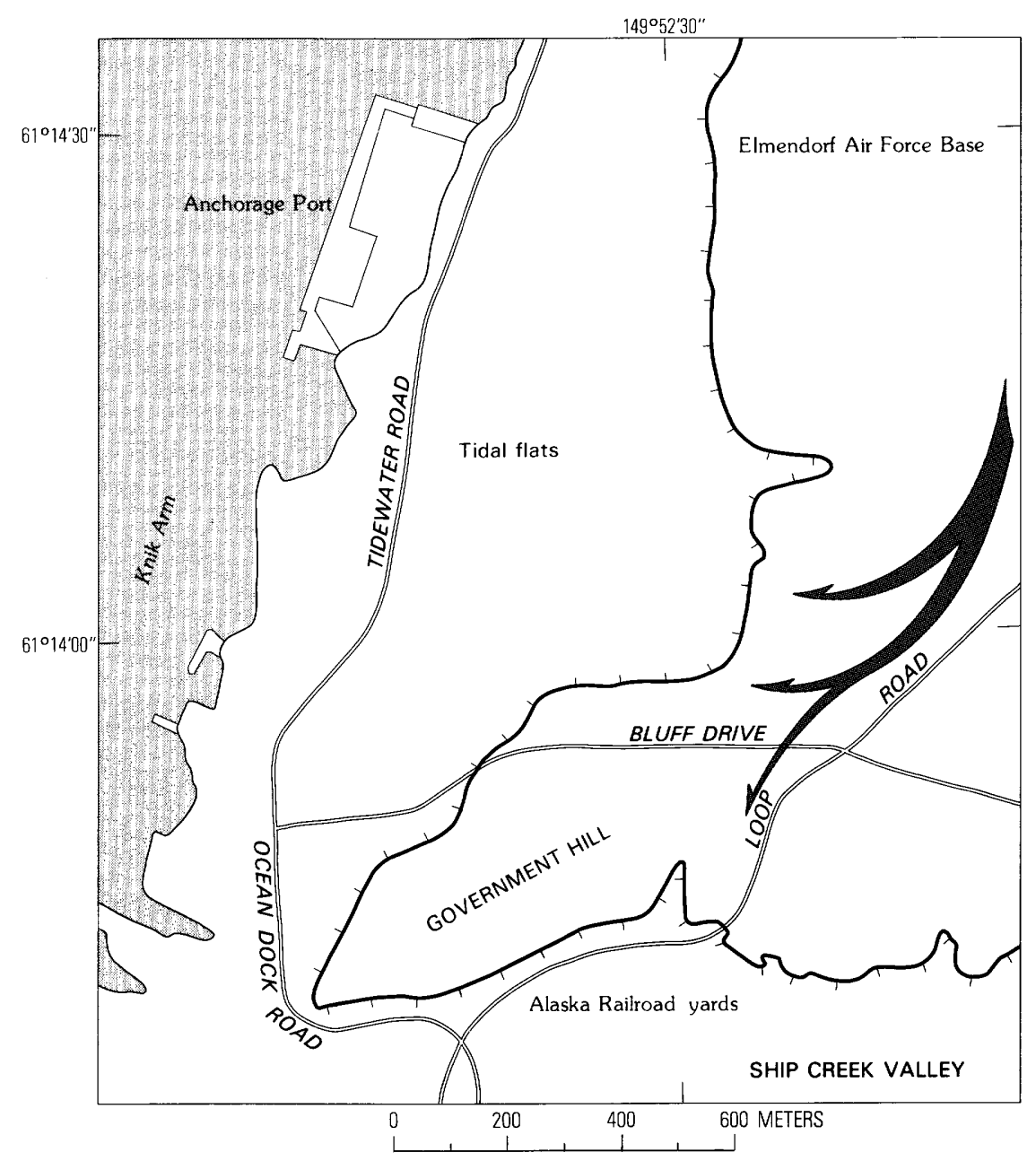

Figure 15. Inferred direction of unconfined ground-water flow (large arrows) beneath uplands of Government Hill area. Hachured line, present-day scarps along upland perimeter. Compare with figure 13 showing distribution of landslides. 
Our primary concern is soil stability in response to seismic events. However, the performance of certain geologic units under aseismic conditions is also significant. The following types of failure should be considered:

1. Liquefaction and consequent failure of cohesionless soils, including flow slides, translational block slides, settlement, and lateral spreading;

2. Strength loss in sensitive clays and consequent failure, including flow slides, translational block slides, and rotational slumps;

3. Failures involving both liquefaction and sensitive clays; and

4. Failures independent of liquefaction and sensitive clays (for example, aseismic gravity free-fall, subsidence, and piping).

The ground failures of the Bootlegger Cove Formation in 1964 prompted considerable research into the cause and mechanics of these slides. A literature search was conducted on two causes, liquefaction of silts and sands (Shannon and Wilson, Inc., 1964; Seed, 1968, 1976; Seed and Wilson, 1967) and failure of sensitive silty clays (Hansen, 1965; Long and George, 1966a; Kerr and Drew, $1965,1968)$. The area has, in fact, become a case-history model for both types of landslide mechanisms, but to 1985 , investigators have not agreed on which mechanism was primarily responsible for the slides, nor decided which is of preeminent concern for potential future failure. Seed (1968) drew the conclusion-based upon cyclic testing data under simulated earthquake conditions, combined with eyewitness accounts-that liquefaction of sand lenses was primarily responsible for initiation of the slides. Once inertial forces were sufficient to overcome the strength of the adjacent sensitive clays, translatory block failures occurred. Seed's work has proven exceedingly important in the recognition of the significant role that liquefaction plays in seismically induced ground failure.

\section{Liquefaction}

The reader is encouraged to review recent literature on the mechanism of seismically induced liquefaction and on how liquefaction potential in noncohesive soils is currently evaluated (Seed, 1976, 1979; Bennett and others, 1981; Seed and Idriss, 1981). Generally, investigators agree that if a saturated, noncohesive soil (ideally a wellsorted sand, but also some clayey sands, silty sands, and gravelly sands) is subjected to seismically induced cyclic shear stresses, soil structure tends to become more compact, resulting in transfer of stress to the pore water and, therefore, diminished stress on the soil particles. If cyclic stresses are sustained, a peak cyclic pore-pressure ratio of 100 percent (Seed, 1979) can be attained; and if cyclic stress is continued, resulting strain can cause "cyclic mo- bility" (Casagrande, 1976). Depending upon the density of the sand, confining pressures, and magnitude of the stress cycles, the soil may be mobilized to unlimited deformation or may experience only limited strain before dilating to a stable condition.

Liquefaction potential of the engineering geologic units described in this report can be assessed by three general approaches:

1. Qualitative assessment, based on geologic criteria commonly recognized as indicators of liquefaction potential;

2. Quantitative assessment, based on field and laboratory soils data that have been used as indicators of performance of noncohesive soils in previous earthquakes;

3. Evaluation of cyclic stress conditions necessary for liquefaction, based on field and laboratory determinations of stress conditions for a given site.

At least 70 of the 246 borehole logs assembled for the present study provide the level of information needed to make a qualitative assessment of liquefaction potential and, when coupled with detailed mapping (Updike, 1986), can give a preliminary evaluation of the liquefaction potential. Sherif and Ishibashi (1978) provided a flow chart for evaluation which we have modified and applied to the engineering geologic units of Government Hill (table 9). If a cohesionless soil unit is at a depth of confinement of $30 \mathrm{~m}$ or more, the soil is usually old enough, and therefore dense enough, not to have sufficient pore-water pressure buildup for liquefaction. In column 2, table 9, a conservative maximum depth of occurrence of $20 \mathrm{~m}$ is used, although some units also occur at greater depths. In order for liquefaction to occur, the soil voids must be saturated with water, which usually means that the soil is at or below the water table (column 3, table 9). Several of the engineering geologic units contain significant quantities of sand, which is a primary consideration for liquefaction. However, the total textural framework of the soil interval must be considered, including sorting, percentages of non-sand-size particles, and packing. If clay, for example, occurs within the sand framework, liquefaction is not likely (Seed and Idriss, 1981). Among the engineering geologic units of Government Hill, few meet these sedimentologic criteria (column 4, table 9). Those that do include Holocene alluvium, tidal flat deposits, Pleistocene glaciofluvial deposits, and F.VI and F. VII of the Bootlegger Cove Formation. The final step (column 5 , table 9) in the preliminary evaluation utilizes the Standard Penetration Test (SPT), wherein a 63-kg mass, dropped from a height of $760 \mathrm{~mm}$, drives a $50.8-\mathrm{mm}$ diameter split-spoon sampler into the ground. The penetration resistance $(N)$ is reported in number of blows of the weight to drive the sampler $305 \mathrm{~mm}$. Although some recorded values can vary significantly, reflecting technique 
and testing conditions (see Gibbs and Holtz, 1957; McLean and others, 1975), the SPT remains the most universally applied test for relative density. Although several correlations have been drawn between SPT and liquefaction potential, the conclusions of Nishiyama and others (1977) are here applied, specifically that critical $N$-values of 0 to 15 should be considered liquefiable. Based on this final parameter, those units which have met the previous liquefaction-potential criteria are more critically defined. For example, SPT values for most layers within the Holocene fluvial sediments of Ship Creek have blow counts generally above 25 and only rarely are at values less than 15, so that capacity for liquefaction is questionable. Conversely, SPT numbers for tidal flat deposits are commonly below 15 to 20 , and those sediments are liquefiable. F.VI and F.VII have $N$ values greater than 20 , so that liquefaction potential is questionable to none.

A second method of evaluating liquefaction potential determines specific field and laboratory properties of noncohesive soils, as described by Seed (1976). The method requires some specific data for the particular stratigraphic sequence as well as some assumptions regarding the seismic input. Careful examination of the available geotechnical data for the $\mathbf{2 4 6}$ boreholes in the study area yielded 41 having sufficient information. Although other site investigations may have actually amassed the neces- sary data for the following analyses, the data did not appear in the reports associated with those investigations and we surmise that they have been lost.

Table 10 summarizes the determinations calculated from the 41 boreholes for sand and silty sand units, respectively. Inch-pound measurement units are used on this table because these units are exclusively reported in the original geotechnical documents from which the data were acquired. For ease of future reference by engineers, inchpound units are likewise used in the following analyses, with metric equivalents in parentheses. Depth to the potentially liquefiable sand, in feet, and depth to groundwater table, also in feet, were given in the borehole logs. Generally, natural-moisture content $\left(W_{n}\right)$ was also given, but where values were not provided, approximations have been used based on numbers from nearby correlative sands. Dry densities $\left(\gamma_{d}\right)$ of the various soil layers including the sand units of interest are generally not provided in borehole logs. Therefore, estimated mean densities $\left(\bar{\gamma}_{d}\right)$ have been used for the calculations, assuming that for sand layers less than $15 \mathrm{ft}(5 \mathrm{~m})$ below ground surface the mean dry-soil density is $100 \mathrm{lb} / \mathrm{ft}^{3}\left(1.6 \mathrm{~g} / \mathrm{cm}^{3}\right)$. Similarly, for sands between 15 and $30 \mathrm{ft}, \bar{\gamma}_{d}=110 \mathrm{lb} / \mathrm{ft}^{3}(1.76$ $\left.\mathrm{g} / \mathrm{cm}^{3}\right)$, and for sands greater than $30 \mathrm{ft}$ below ground surface $\bar{\gamma}_{d}=120 \mathrm{lb} / \mathrm{ft}^{3}\left(1.92 \mathrm{~g} / \mathrm{cm}^{3}\right)$. These divisions are somewhat arbitrary but are supported by available density

Table 9. Qualitative assessment of the liquefaction potential for engineering-geologic map units, Bootlegger Cove Formation, Government Hill area

\begin{tabular}{|c|c|c|c|c|c|}
\hline $\begin{array}{l}\text { Map } \\
\text { unit }\end{array}$ & $\begin{array}{l}\text { At } 20 \mathrm{~m} \text { or } \\
\text { less below } \\
\text { surface }\end{array}$ & $\begin{array}{c}\text { Water } \\
\text { table } \\
\text { wrt } \\
\text { unit }^{1}\end{array}$ & $\begin{array}{l}\text { Grain-size } \\
\text { distribution }\end{array}$ & $\begin{array}{l}\text { Penetration } \\
\text { resistance }\end{array}$ & $\begin{array}{l}\text { Liquefaction } \\
\text { potential }\end{array}$ \\
\hline F.I . . . . . . & Yes & Above & Clay - & & Nonliquefiable. \\
\hline F.II $\ldots \ldots \ldots$ & No - & & & & Nonliquefiable. \\
\hline F.III . . . . . . & No - & & & & Nonliquefiable. \\
\hline F.IV . . . . . . & Yes & Above & Silt and clay - & & Nonliquefiable. \\
\hline F.V $\ldots \ldots \ldots$ & Rare & Above & Silt and clay - & & Nonliquefiable. \\
\hline F.VI . . . . . & Yes & Above & Silt and sand & $>20 \longrightarrow$ & Questionable. \\
\hline F.VII . . . . . . & Yes & Above & Sand with gravel & $>20 \longrightarrow$ & Questionable. \\
\hline $\begin{array}{l}\text { Glaciofluvial } \\
\text { deposits. }\end{array}$ & Yes & In or above & Silt/sand/gravel & $8-65 \rightarrow$ & Questionable. \\
\hline Tidal flat deposits. . . & Yes & In or above & Silt/sand/gravel & $4-55 \rightarrow$ & Liquefiable. \\
\hline $\begin{array}{l}\text { Tidal marsh } \\
\text { deposits. }\end{array}$ & Yes & Above/below & Silt/sand organic & $1-12 \rightarrow$ & Questionable. \\
\hline Landslide deposits . . & Yes & Discontinuous & Clay to gravel & $2-18 \rightarrow$ & Questionable. \\
\hline Holocene alluvium . . & Yes & $\begin{array}{l}\text { Within top } \\
3 \mathrm{~m} \text {. }\end{array}$ & Silt to gravel & $5-70 \longrightarrow$ & Questionable. \\
\hline Man-related fill $\cdots$ & Yes & Below & & & Nonliquefiable. \\
\hline
\end{tabular}

${ }^{1}$ wrt, with respect to. 
Table 10. Tabulation of borehole data and computed values utilized to evaluate liquefaction potential

\begin{tabular}{|c|c|c|c|c|c|c|c|c|c|c|c|}
\hline $\begin{array}{c}\text { Sample } \\
\text { No. }\end{array}$ & $\begin{array}{c}\text { Depth to } \\
\text { top of } \\
\text { interval } \\
\text { (feet) }\end{array}$ & $\begin{array}{l}\text { Water } \\
\text { table } \\
\text { depth } \\
\text { (feet) }\end{array}$ & $\begin{array}{c}\text { Natural } \\
\text { moisture } \\
\text { content } \\
(p c t) \\
W_{n}\end{array}$ & $\begin{array}{c}\text { Total } \\
\text { vertical } \\
\text { stress } \\
\left(\mid \mathrm{b} / \mathrm{ft}^{2}\right) \\
\sigma_{v}\end{array}$ & $\begin{array}{c}\text { Effective } \\
\text { overburden } \\
\text { pressure } \\
\left(\mathrm{lb} / \mathrm{ft}^{2}\right) \\
\bar{\sigma}_{v}\end{array}$ & $\begin{array}{l}\text { Static } \\
\text { stress } \\
\text { ratio } \\
\sigma_{v^{\prime}} \bar{\sigma}_{v}\end{array}$ & $\begin{array}{c}\text { Stress } \\
\text { reduc- } \\
\text { tion } \\
\text { factor } \\
r_{d}\end{array}$ & $\begin{array}{c}\text { Cyclic } \\
\text { stress } \\
\text { ratio } \\
\tau_{a v} / \bar{\sigma}_{v}\end{array}$ & $\begin{array}{c}\text { Penetration } \\
\text { resistance } \\
\text { (blows/ft) } \\
N\end{array}$ & $\begin{array}{c}\text { Dimensionless } \\
\text { conversion } \\
\text { factor } \\
C_{N}\end{array}$ & $\begin{array}{c}\text { Corrected } \\
\text { penetration } \\
\text { resistance } \\
\text { (blows/ft) } \\
N_{1}\end{array}$ \\
\hline \multicolumn{12}{|c|}{ Tidal flat sands } \\
\hline 2D & 39 & 1 & 24 & 5,811 & 4,709 & 1.23 & 0.87 & 0.21 & 26 & 1.06 & 28 \\
\hline $2 \mathrm{E}$ & 45 & 1 & 20 & 6,480 & 5,424 & 1.19 & .85 & .20 & 10 & 1.02 & 10 \\
\hline 3 & 37 & 7 & 16 & 5,143 & 4,573 & 1.12 & .88 & .19 & 78 & 1.00 & 78 \\
\hline $4 \mathrm{~A}$ & 40 & 6 & 23 & 5,920 & 4,968 & 1.19 & .87 & .20 & 38 & .99 & 38 \\
\hline 4B & 44 & 6 & 23 & 6,512 & 5,448 & 1.20 & .85 & .20 & 44 & .96 & 42 \\
\hline $4 C$ & 50 & 6 & 19 & 7,150 & 6,138 & 1.16 & .83 & .19 & 78 & .92 & 72 \\
\hline 5 & 46 & 2 & 21 & 6,670 & 5,570 & 1.20 & .85 & .20 & 54 & .98 & 53 \\
\hline 6 & 45 & 0 & 21 & 6,525 & 5,400 & 1.21 & .85 & .20 & 52 & 1.02 & 53 \\
\hline
\end{tabular}

Glaciofluvial sands

\begin{tabular}{|c|c|c|c|c|c|c|c|c|c|c|c|}
\hline $42 \mathrm{~A}$ & 7 & 6 & 25 & 875 & 850 & 1.03 & 0.95 & 0.19 & 8 & 1.60 & 13 \\
\hline $42 B$ & 12 & 6 & 25 & 1,500 & 1,350 & 1.11 & .95 & .21 & 13 & 1.44 & 20 \\
\hline $42 \mathrm{C}$ & 17 & 6 & 25 & 2,346 & 2,038 & 1.15 & .94 & .21 & 20 & 1.26 & 25 \\
\hline 42D & 21 & 6 & 25 & 2,898 & 2,478 & 1.17 & .93 & .21 & 8 & .92 & 7 \\
\hline $43 \mathrm{~A}$ & 9 & 6 & 25 & 1,125 & 1,050 & 1.07 & .97 & .20 & 12 & 1.60 & 19 \\
\hline 43B & 12 & 6 & 25 & 1,500 & 1,350 & 1.11 & .96 & .21 & 13 & 1.44 & 19 \\
\hline $43 C$ & 16 & 6 & 25 & 2,208 & 1,928 & 1.15 & .95 & .21 & 22 & 1.28 & 28 \\
\hline 43D & 19 & 6 & 25 & 2,622 & 2,258 & 1.16 & .93 & .21 & 21 & 1.24 & 26 \\
\hline 44 & 15 & 6 & 25 & 1,875 & 1,650 & 1.14 & .95 & .21 & 12 & 1.30 & 16 \\
\hline $62 \mathrm{~A}$ & 6 & 0 & 25 & 750 & 600 & 1.25 & .98 & .19 & 30 & 1.60 & 48 \\
\hline 62B & 11 & 0 & 25 & 1,375 & 1,100 & 1.25 & .96 & .23 & 28 & 1.60 & 45 \\
\hline $73 \mathrm{~A}$ & 11 & 2 & 25 & 1,375 & 1,150 & 1.20 & .96 & .22 & 17 & 1.60 & 27 \\
\hline $73 B$ & 15 & 2 & 25 & 1,875 & 1,550 & 1.21 & .95 & .22 & 10 & 1.50 & 15 \\
\hline $73 C$ & 10 & 2 & 25 & 1,250 & 1,050 & 1.19 & .97 & .25 & 13 & 1.60 & 21 \\
\hline \multicolumn{12}{|c|}{ Tidal flat silty sands } \\
\hline 36 & 26 & 3 & 24 & 3,536 & 2,938 & 1.20 & 0.91 & 0.21 & 55 & 1.12 & 69 \\
\hline 37 & 26 & 6 & 21 & 3,458 & 2,998 & 1.15 & .91 & .20 & 40 & 1.06 & 50 \\
\hline 202 & 61 & 39 & 30 & 9,516 & 8,364 & 1.14 & .80 & .18 & 50 & .60 & 38 \\
\hline
\end{tabular}

F.VI of the Bootlegger Cove Formation

\begin{tabular}{|c|c|c|c|c|c|c|c|c|c|c|c|}
\hline $1 \mathrm{~A}$ & 10 & 0 & 25 & 1,250 & 100 & 1.25 & 0.97 & 0.23 & 24 & 1.60 & 46 \\
\hline 1B & 15 & 0 & 29 & 1,935 & 1.500 & 1.29 & .95 & .24 & 13 & 1.60 & 33 \\
\hline 1C & 22 & 0 & 30 & 3,146 & 2,420 & 1.30 & .93 & .24 & 13 & 1.42 & 26 \\
\hline $2 \mathrm{~A}$ & 15 & 1 & 30 & 1,950 & 1,530 & 1.27 & .95 & .24 & 7 & 1.51 & 18 \\
\hline 2B & 20 & 1 & 27 & 2,800 & 2,230 & 1.26 & .93 & .23 & 14 & 1.44 & 28 \\
\hline $2 \mathrm{C}$ & 25 & 1 & 28 & 3,525 & 2,781 & 1.27 & .91 & .23 & 9 & 1.31 & 19 \\
\hline $7 \mathrm{~A}$ & 10 & 0 & 19 & 1,190 & 1,000 & 1.19 & .97 & .23 & 29 & 1.60 & 54 \\
\hline $7 B$ & 15 & 0 & 32 & 1,980 & 1,500 & 1.32 & .95 & .24 & 11 & 1.60 & 25 \\
\hline $7 \mathrm{C}$ & 21 & 0 & 18 & 2,730 & 2,310 & 1.18 & .93 & .21 & 14 & 1.42 & 27 \\
\hline 7D & 47 & 0 & 26 & 7,097 & 5,640 & 1.26 & .84 & .21 & 46 & 1.00 & 54 \\
\hline $7 \mathrm{E}$ & 53 & 0 & 18 & 7,526 & 6,360 & 1.18 & .82 & .19 & 78 & .96 & 83 \\
\hline $12 \mathrm{~A}$ & 5 & 1 & 31 & 655 & 531 & 1.23 & .99 & .24 & 23 & 1.60 & 44 \\
\hline $12 \mathrm{~B}$ & 13 & 1 & 25 & 1,625 & 1,325 & 1.23 & .95 & .23 & 23 & 1.60 & 44 \\
\hline $12 \mathrm{C}$ & 30 & 1 & 24 & 4,080 & 3,326 & 1.23 & .90 & .22 & 29 & 1.20 & 42 \\
\hline $12 \mathrm{D}$ & 43 & 1 & 20 & 6,192 & 5,184 & 1.19 & .85 & .20 & 92 & 1.06 & 105 \\
\hline 17 & 35 & 0 & 28 & 5,390 & 4,200 & 1.28 & .88 & .22 & 64 & 1.13 & 80 \\
\hline
\end{tabular}


data, and the modest discrepancies that may actually exist will not significantly affect the following calculations. The total vertical stress, $\sigma_{v}$, can be calculated from these data (the reader may wish to consult a soils-engineering text for the required calculations, for example, Dunn and others, 1980). Because the layers under consideration exist below the water table, that is, are under saturated conditions, it is necessary to compute the pore-water pressure, $U$, and subtract this value from $\sigma_{v}$ to obtain the effective overburden pressure, $\bar{\sigma}_{v}$, or effective stress. The results of these calculations also appear in table 10 .

The cyclic stress ratio, $\tau_{a} / \bar{\sigma}_{v}$, as proposed by Seed (1976, 1979), is a meaningful parameter for expressing cyclic liquefaction potential as a ratio of the average cyclic shear stress acting on horizontal surfaces within the soil as a result of seismic loading, $\tau_{a v}$, to the initial effective vertical stress acting on the soil layer before cyclic loading, $\bar{\sigma}_{v}$. This ratio can be computed from

$$
\frac{\tau_{a v}}{\overline{\bar{\sigma}}_{v}} \approx 0.65 \cdot \frac{a_{\max }}{g} \cdot \frac{\sigma_{v}}{\overline{\bar{\sigma}}_{v}} \cdot r_{d}
$$

where $a_{\max } / g$ is the maximum estimated earthquake acceleration at the ground surface with respect to gravitational acceleration and $r_{d}$ is a stress-reduction factor which varies from a value of 1 at the ground surface to 0.9 at a depth of $30 \mathrm{ft}$ (Seed, 1979). Table 10 gives the calculated values of the cyclic stress ratio using the interpolated values of $r_{d}$ and assuming $a_{\mathrm{max}} / g=0.3$.

The SPT blow-count (blows per foot) information ( $N$ values) is utilized as a measure of relative density. Based on the work of Gibbs and Holtz (1957), a corrected penetration resistance, $N_{1}$, is proposed by Seed (1976) as

$$
N_{1}=\mathrm{C}_{N} \cdot N
$$

where $\mathrm{C}_{N}$ is a dimensionless conversion factor. The appropriate values of $\mathrm{C}_{N}$ have been determined from the curves published by Seed and Idriss (1981) (this report, fig. 16). The potential for liquefaction of silty sands is substantially less than for clean sands. Seed (1979) has shown that a factor of 7.5 should be added to the $N_{1}$ values for silty sands; where applicable this is reflected in the $N_{1}$ values of table 10. Following the method of Seed (1979), the corrected penetration, $N_{1}$, is plotted against the cyclic stress ratio, $\tau_{a v} / \bar{\sigma}_{v}$, in figures 17 and 18. Seed and others (1977) were able to draw a liquefaction-potential boundary line on this graph based on historical data from liquefaction sites. A suite of curves for different magnitude earthquakes have been subsequently developed by Seed and Idriss (1981) and are plotted on the graphs (figs. 17, 18). Data points falling to the left of a particular curve should be considered as representing sands or silty sands which are liquefiable under earthquake conditions equivalent to the magnitude of the curve.

Several glaciofluvial sand data points fall within or to the left of the suite of curves (fig. 17). These are saturated, moderate to loosely packed sands overlying the Bootlegger Cove Formation. The data points for tidal flat sands (fig. 17) and tidal flat silty sands (fig. 18) are generally in the nonliquefiable field, although enough points fall within the liquefiable domain to give some concern for tidal flat stability in earthquakes of magnitudes greater than 6. Three values for F.VI silty sands are also given in figure 18, all decidedly nonliquefiable. This is supported by the work of Idriss and Moriwaki (1982) for sands within the Bootlegger Cove Formation elsewhere in Anchorage, which they also concluded are nonliquefiable. Estimating liquefaction potential by this series of measurements and calculations is well within the scope and capabilities of most site-foundation studies, and this increment of additional work is strongly recommended for future construction in the Anchorage area.

The third technique for evaluating liquefaction potential, utilizing the determinations of in-place stress con-

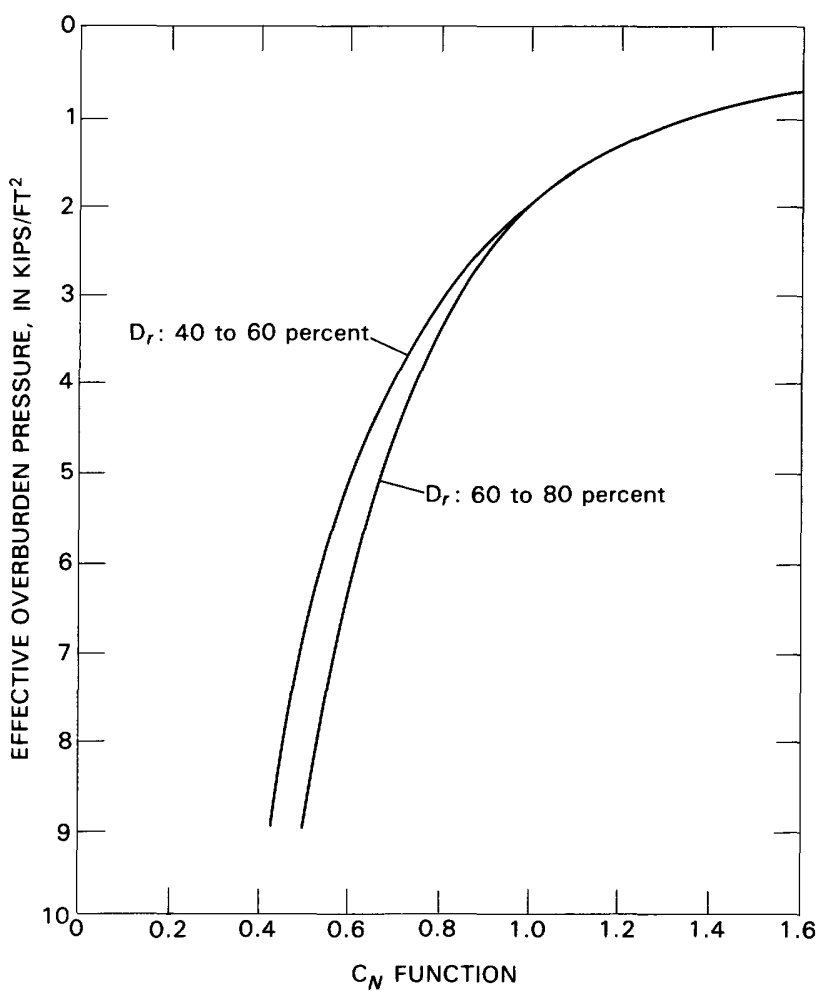

Figure 16. Graph for determining $C_{N}$ as a function of effective overburden pressure, modified from Seed and Idriss (1981). Relative density $\left(D_{r}\right)$ should be considered at effective overburden pressures greater than 2,000 pounds per square foot $\left(95.8 \mathrm{kN} / \mathrm{m}^{2}\right)$. 
ditions and relating these data to laboratory cyclic stress determinations, is far more rigorous than the first two methods (Castro and Poulos, 1976; Cho and others, 1976). To date of this writing, this type of study has not been performed in the Government Hill area.

Based on the foregoing analyses, the role that liquefaction played in the 1964 earthquake ground failures is in doubt. Some of the ground cracking and minor displacements that occurred on the tidal flats and Ship Creek flood plain were most probably a result of liquefaction. The Government Hill Elementary School and Elmendorf slides were due to failures within the Bootlegger Cove Formation. Typically, the very soft silty clay units are directly above or below the sand facies, which may have confused the failure plane analyses. The work of Shannon and Wilson, Inc. (1964), and Seed (1967) indicates that under cyclic loading the sands would fail before the sensitive clays. Some question remains about the 1964 method of testing using reconstituted sands as well as about inherent errors in the in-place strength measurements of F.III. Based upon the calculations summarized in this report, we must conclude that the Government Hill Elementary School and Elmendorf slides are not the result of sand liquefaction, as previously proposed.

\section{Sensitive Silty Clays}

The origin of the silty clays of the Bootlegger Cove Formation in quiet brackish to saline water is compatible

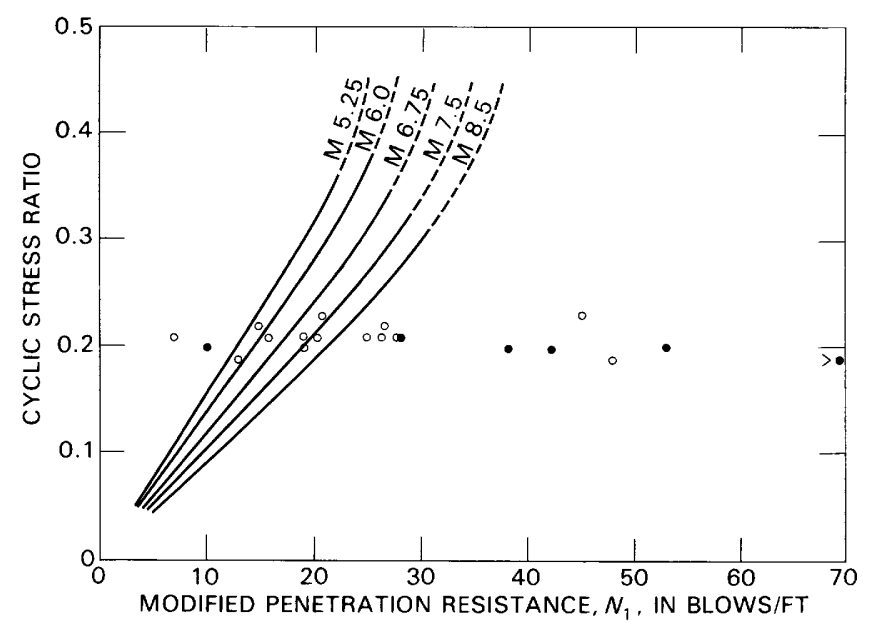

EXPLANATION

- Tidal flat sand

- Glaciofluvial sand

Figure 17. Liquefaction potential for tidal flat sands and glaciofluvial sands. Earthquake magnitude boundary curves from Idriss and Moriwaki (1982), dashed where inferred; $a_{\max }$ (maximum seismic acceleration), $0.30 \mathrm{~g}$. Points falling within or to left of curves are potentially liquefiable. with the formation of an open flocculated framework of soil particles. This, in itself, may not fully account for the sensitivity of certain layers within the formation (that is, F.III). Six causes for clay sensitivity have been proposed by Mitchell (1976), including (1) metastable fabric, (2) cementation, (3) weathering, (4) thixotropic hardening, (5) leaching and ion exchange, and (6) formation or addition of dispersing agents. Seemingly, the most apparent cause of increased local sensitivity for the Bootlegger Cove Formation is the prehistoric fluctuations of sea level with associated salt leaching within the flocculated structure.

In addition, some evidence suggests that soils such as F.III can attain moderate sensitivity by way of thixotropic hardening (Mitchell, 1960). The process requires remolding after the initial sedimentation, followed by relaxation of the externally applied stresses. This process allows for a reorganization of the interparticle force balance and a tendency toward flocculation of particles in a newly established water-cation structure. We visualize this process as not being responsible for the initial sensitivity of F.III (which relates to the original undisturbed framework of the soil), but being instead a supplementary mechanism to enhance sensitivity. Thixotropic hardening would thus play an important role in areas adjacent to those which have failed massively. The effect of limited shear strain during prior seismic events serves as the mechanism for remolding the silty clays along failure planes and, in fact, expands the sensitive zone vertically

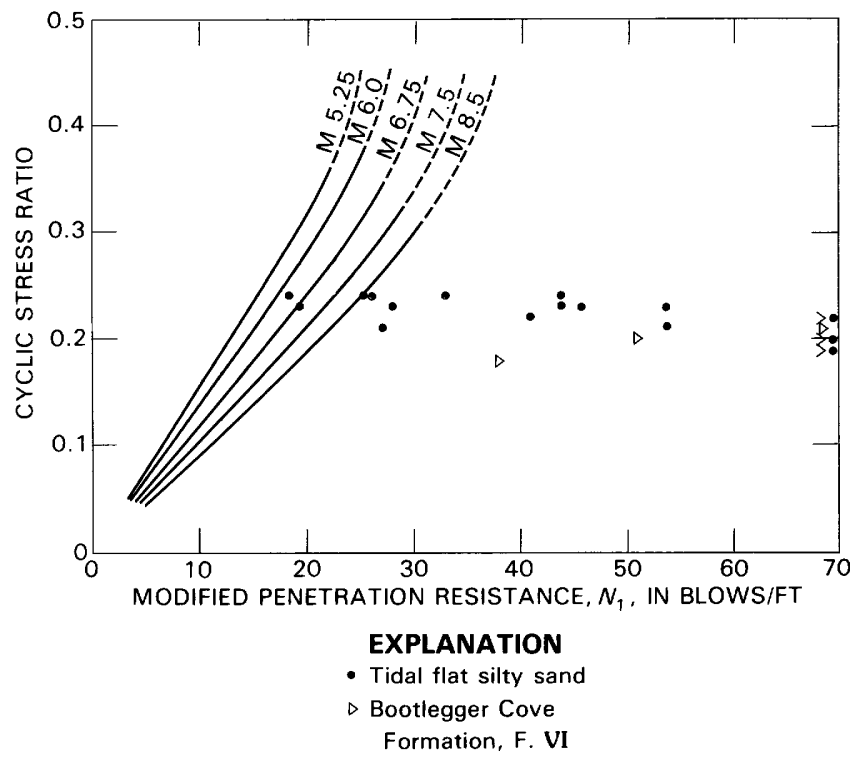

Figure 18. Liquefaction potential for tidal flat silty sands and F.VI (Bootlegger Cove Formation). Earthquake-magnitude boundary curves from Idriss and Moriwaki (1982), dashed where inferred; $a_{\max }$ (maximum seismic acceleration), $0.30 \mathrm{~g}$. 
during successive earthquakes over a period of hundreds of years.

Under shear stresses, such as those induced by an earthquake, the flocculated structure of F.III collapses with an attendant decrease in volume. F.III is normally confined by low-permeability facies (for example, F.II and F.IV), and if the drainage of pore water is too slow, effective stresses in the zone of collapse would approach zero, resulting in lateral flow and low-angle planar gliding.

The translatory failure affects the overlying units, typically resulting in block movement along numerous secondary shear planes. Although the initial movement may closely resemble liquefaction along deep cohesionless horizons, the sensitive clay failure would be more likely to continue after the cyclic shear stresses cease. At Turnagain Heights during the 1964 earthquake, the apparent continuation of ground failure after the ground shaking had ended (Hansen, 1965) was probably due to sensitive clay mobilization. The two major landslides that occurred at Government Hill were related to shear planes developed above MSL within the Bootlegger Cove Formation. At both locations, F.VI and the sensitive F.III occur at the probable depth of initial failure. Both areas have higher than normal amounts of ground water and surface runoff, which combine with the factor of a steep free-face bluff line to increase slope instability.

\section{Other Mechanisms}

In addition to failures resulting from liquefaction and sensitive clays, soils within the study area have shown potential for vertical and (or) lateral displacement due to a variety of other stress-field conditions. As indicated earlier in this report, numerous landslides have happened along the bluff scarps, often independent of seismic events. These slides may have various natural or man-related causes, which include over-steepened slopes; undercutting of the toe of the slope; ground-water piping, which removes cohesionless soils from within or below slopes; induced loading at the head of, or directly on, the freeface slope; and lateral spreading or slumping due to removal of buttressing material. Separation of the moving blocks typically occurs along high-angle shear planes at shallow depths (less than $10 \mathrm{~m}$ ) behind the free face, with vertical displacements from 1.0 to $15 \mathrm{~m}$.

Surface fissures, heaving, and subsidence of fill and regraded soils are occasionally reported in those areas of near-horizontal slopes. These failures are limited in displacement to a few centimeters but can cause disruptions of foundations, utilities, pipelines, and roadways. In most instances, failure can be attributed to unstable soil conditions below the fill grade. These include soils that are poorly drained and have high organic content, are poorly consolidated, have low shear strength due to previous fail- ure, are overconsolidated subgrade cohesive soils, have lateral variation of subgrade soil types resulting in differential settlement, or contain artificially induced permafrost beneath fluid storage tanks. In most instances, site foundation engineering has been inadequate. Subgrade excavation, soil improvement using admixtures, subgrade drains, compaction, and modification of fill thickness and composition provide the necessary remedy for most of these problems.

\section{SUMMARY}

The Government Hill-Anchorage Port-Ship Creek area is a critical transportation center for Alaska. The potential landslide hazard throughout the area could seriously impact upon its operation. Certain facies within the Bootlegger Cove Formation are here of particular concern, especially during possible future seismic events. Previous slope failures exist nearly continuously along the entire bluff line around Government Hill and north to beyond Cherry Hill, where slides then become discontinuous. The primary mode of failure is by slump blocks, which may have rotational or inclined glide-plane displacement. Larger blocks tend to break up upon movement into smaller entities, which may move either in retrograde or normal rotational dislocations. The 1964 Government Hill Elementary School slide was typical of the majority of these slides along the bluffs. Major slides show a rather consistent range of vertical displacement $(6-10 \mathrm{~m})$, but vary distinctly in volume according to the horizontal area of the moving block, or blocks. Two areas have particularly marked earlier histories of failures: the area north from the military P.O.L. tank farm approximately $1 \mathrm{~km}$ and the southeastern segment of Government Hill near the old Government Hill Elementary School. The 1964 slides were located in these same areas, and both slides appear to have partially involved soil masses which had already failed tens to hundreds of years prior to 1964 . Little evidence for landslides was found in the northernmost part of the study area: a change in the dominant facies of the Bootlegger Cove Formation (F.III being replaced by F.II and F.IV) increased effective overburden, and we also see evidence for late Pleistocene glacial loading of the sedimentary sequence, which caused overconsolidation. In all instances, landslides along the Government Hill bluffs can be attributed to failures within the Bootlegger Cove Formation. We conclude that most of this mass movement, including the 1964 slides, is due to sensitive clay failure; sand liquefaction played no significant role. The clay failure problem is further enhanced by ground-water and surface-runoff conditions; that is, where ground water is discharging from above or within the Bootlegger Cove Formation to the surface, recent slope failures are far more extensive. 
Based on an examination of the distribution and character of Holocene landslides along the bluffs and on present activity (ground fissures, slope deformation, and surfacing waters), we are particularly concerned for the slope stability of the area extending from West Bluff Drive, north through the P.O.L. tank farm, and thence north to the bluffs just south of Cherry Hill. This area includes both former slides below the present bluff line and upland surfaces within $700 \mathrm{~m}$ of the existing bluffs.

We have tried here to develop a method for examining the three-dimensional characteristics of the Quaternary deposits that occur in the Government Hill area of Anchorage, with particular emphasis on the variability of the Bootlegger Cove Formation. The relations among the geologic history, present ambient geologic conditions, and engineering characteristics of each mappable geologic unit dictate the three-dimensional behavior of the soils in a given site. Although our available data provide an adequate base for characterizing the static parameters of each unit, the data do not provide sufficient information for an adequate assessment under dynamic conditions. In this sense, based upon the high seismic exposure of the area and the observed and recorded performance of certain of these soils, a strong plea is made for a more unified approach to site foundation testing and assessment throughout Anchorage.

\section{REFERENCES CITED}

Barnwell, W. W., George, R. S., Dearborn, L. L., Weeks, J. B., and Zenone, C., 1972, Water for Anchorage, an atlas of the water resources of the Anchorage area, Alaska: City of Anchorage and the Greater Anchorage Area Borough, $77 \mathrm{p}$.

Bennett, M. J., Youd, T. L., Harp, E. L., and Wieczorek, G. F., 1981, Subsurface investigation of liquefaction, Imperial Valley earthquake, California, October 15, 1979: U.S. Geological Survey Open-File Report 81-502, 83 p.

Brown, L. D., Reilinger, R. E., Holdahl, S. R., and Balzaks, E. I., 1977, Post-seismic crustal uplift near Anchorage, Alaska: Journal of Geophysical Research, v. 82, p. 33693378.

Casagrande, Arthur, 1976, Liquefaction and cyclic deformation of sands-A critical review: Harvard University Soil Mechanics Series, no. 88, 51 p.

Castro, Gonzalo, and Poulos, S. J., 1976, Factors affecting liquefaction and cyclic mobility: American Society of Civil Engineers Symposium on Soil Liquefaction, p. 105-173.

Cederstrom, D. J., Trainer, F. W., and Waller, R. M., 1964, Geology and ground-water resources of the Anchorage area, Alaska: U.S. Geological Survey Water Supply Paper 1773, $108 \mathrm{p}$.

Cho, Y., Rizzo, P. C., and Humphries, W. K., 1976, Saturated sand and cyclic dynamic tests: American Society of Civil Engineers Symposium on Soil Liquefaction, p. 285-312.

Dunn, I. S., Anderson, L. R., and Kiefer, F. W., 1980, Funda- mentals of geotechnical analysis: New York, John Wiley, $414 \mathrm{p}$.

Fogelman, K. A. Stephens, C. D., Lahr, J. C., Helton, S. M., and Allen, M. A., 1978, Catalogue of earthquakes in southern Alaska, October-December, 1977: U.S. Geological Survey Open-File Report 78-1097, 28 p.

Gibbs, H. J., and Holtz, W. G., 1957, Research on determining the density of sands by spoon penetration testing: Proceedings, 4th International Conference on Soil Mechanics and Foundation Engineering, v. 1, p. 35-39.

Hansen, W. R., 1965, Effects of the earthquake of March 27, 1964, at Anchorage, Alaska: U.S. Geological Survey Professional Paper 542-A, $68 \mathrm{p}$.

Idriss, I. M., and Moriwaki, Yoshiharu, 1982, Anchorage State Office Complex geotechnical investigation, Anchorage, Alaska, Volume 1, Seismic hazards evaluation: San Francisco, Woodward-Clyde Consultants, p. 6-1 to 6-3.

Karlstrom, T. N. V., 1964, Quaternary geology of the Kenai Lowland and glacial history of the Cook Inlet region, Alaska: U.S. Geological Survey Professional Paper 443, 69 p.

Kerr, P. F., and Drew, I. M., 1965, Quick clay movements, Anchorage, Alaska: Springfield, Virginia, National Technical Information Service, Document AD630-111, 133 p.

1968, Quick-clay slides in the U.S.A.: Engineering Geology-An International Journal, v. 2, p. 215-238.

Lambe, T. W., and Whitman, R. V., 1979, Soil mechanics, SI version: New York, John Wiley, $553 \mathrm{p}$.

Long, Erwin, and George, Warren, 1966a, Buttress design earthquake-induced slides: Soil Mechanics and Foundations Division, American Society of Civil Engineers, Conference on Stability and Performance of Slopes and Embankments, Berkeley, Calif., p. 657-671.

1966b, Turnagain slide stabilization, Anchorage, Alaska: Soil Mechanics and Foundations Division, American Society of Civil Engineers, Conference on Stability and Performance of Slopes and Embankments, Berkeley, Calif., p. 673-689.

McLean, F. G., Franklin, A. G., and Dahlsrand, T. K., 1975, Influence of mechanic variables on the SPT: Geotechnical Engineering Division, American Society of Civil Engineers, Proceedings Conference on in situ Measurement of Soil Properties, v. 1, p. 287-318.

Miller, R. D., and Dobrovolny, Ernest, 1959, Surficial geology of Anchorage and vicinity, Alaska: U.S. Geological Survey Bulletin 1093, 128 p.

Mitchell, J. K., 1960, Fundamental aspects of thixotropy in soils: Journal of Soil Mechanics and Foundations Division, American Society of Civil Engineers, v. 86, p. 19-52.

1976, Fundamentals of soil behavior: New York, John Wiley, $422 \mathrm{p}$.

Nishiyama, H., Yahagi, K., Nakagawa, S., and Wada, K., 1977, Practical method of predicting sand liquefaction: Proceedings, 9th International Conference on Soil Mechanics and Foundation Engineering, Tokyo, v. 2, p. 305-308.

Passega, R. M., 1957, Texture as characteristic of clastic deposition: American Association of Petroleum Geologists Bulletin, v. 41, p. 1952-1984.

1964, Grain size representation by CM patterns as a geologic tool: Journal of Sedimentary Petrology, v. 34, p. 830-847. 
Plafker, George, 1969, Tectonics of the March 27, 1964, Alaska earthquake: U.S. Geological Survey Professional Paper 543I, $74 \mathrm{p}$.

Reger, R. D., and Updike, R. G., 1983, Upper Cook Inlet region and the Matanuska Valley, in Péwé, T. L., and Reger, R. D., Richardson and Glenn Highways-Guidebook to permafrost and Quaternary geology: Alaska Division of Geological and Geophysical Surveys, Guidebook 1, p. 185263.

Schmidt, R. A. M., 1963, Pleistocene marine microfauna in the Bootlegger Cove Clay, Anchorage area, Alaska: Science, v. 141 , no. 3578 , p. $350-351$.

Schmoll, H. R., and Dobrovolny, Ernest, 1972, Generalized geologic map of Anchorage and vicinity, Alaska: U.S. Geological Survey Miscellaneous Investigations Map I-787A, scale 1:24,000.

Schmoll, H. R., Szabo, B. J., Rubin, Meyer, and Dobrovolny, Ernest, 1972, Radiometric dating of marine shells from the Bootlegger Cove Clay, Anchorage area, Alaska: Geological Society of America Bulletin, v. 83, p. 1107-1114.

Schmoll, H. R., Yehle, Lynn, Gardner, C. A., and Odum, J. K., 1984, Guide to surficial geology and glacial stratigraphy in the upper Cook Inlet basin: Alaska Geological Society Field Trip Guidebook, p. 26.

Seed, H. B., 1968, Landslides during earthquakes due to soil liquefaction: Journal of the Soil Mechanics and Foundations Division, American Society of Civil Engineers, v. 94, p. 1053-1122.

1976, Evaluation of soil liquefaction effects on level ground during earthquakes: American Society of Civil Engineers Specialty Session on Liquefaction Problems in Geotechnical Engineering, Philadelphia, p. 1-104.

1979, Soil liquefaction and cyclic mobility evaluation for level ground during earthquakes: Journal of the Geotechnical Engineering Division, American Society of Civil Engineers, v. 105, p. 201-255.

Seed, H. B., and Idriss, I. M., 1981, Evaluation of liquefaction potential of sand deposits based on observation of performance in previous earthquakes: American Society of Civil Engineers Preprint 81-544, 21 p.
Seed, H. B., and Wilson, S. D., 1967, The Turnagain Heights landslide, Anchorage, Alaska: Journal of the Soil Mechanics and Foundations Division, American Society of Civil Engineers, v. 93, p. 325-353.

Shannon and Wilson, Inc., 1964, Report on Anchorage area soil studies, Alaska to the U.S. Army Engineer District, Anchorage, Alaska: Seattle, Wash., Shannon and Wilson, Inc., 109 p.

Sheridan, M. F., and Updike, R. G., 1975, Sugarloaf Mountain tephra-a Pleistocene rhyolitic deposit of base surge origin in northern Arizona: Geological Society of America Bulletin, v. 86 , p. $571-581$.

Sherif, M. A., and Ishibashi, I., 1978, Soil dynamics considerations for microzonation: Proceedings, 2d International Conference on Microzonation, San Francisco, v. 1, p. 81-110.

Smith, P. J., 1964, Foraminifera from the Bootlegger Cove Clay, Anchorage, Alaska, in Report on Anchorage area soil studies, Alaska: Seattle, Wash., Shannon and Wilson, Inc., Appendix J, p. J1-J5.

Torrance, J. K., 1974, A laboratory investigation of the effect of leaching on the compressibility and shear strength of Norwegian marine clays: Geotechniques, v. 24, p. 155-173.

Trainer, F. W., and Waller, R. M., 1965, Subsurface stratigraphy of glacial drift at Anchorage, Alaska, in Geological Survey research 1965: U.S. Geological Survey Professional Paper 525-D, p. D167-D174.

Updike, R. G., 1986, Engineering geologic maps, Government Hill area, Anchorage, Alaska: U.S. Geological Survey Miscellaneous Investigations Map I-1610.

Updike, R. G., Cole, D. A., Jr., and Ullery, Cathy, 1982, Shear moduli and damping ratios for the Bootlegger Cove Formation as determined by resonant-column testing, in Short Notes on Alaskan geology, 1981: Alaska Division of Geology and Geophysical Survey Geologic Report 73, p. 7-12.

Varnes, D. J., 1969, Stability of the west slope of Government Hill port area of Anchorage, Alaska: U.S. Geological Survey Bulletin 1258-D, p. D1-D61. 
